\title{
The Study of Bias in Entrepreneurship
}

Scholars use the theoretical lens of bias to research various behavioral phenomena in entrepreneurship. We assess this body of research, focusing on definitional issues and relationships. Furthermore, we discuss how the study of bias in entrepreneurship can be advanced, given the new development in related fields such as cognitive sciences. The assessments and discussions help reveal as well as address tensions in the literature, identify numerous research opportunities that may not be obvious by looking at previous work individually, and contribute to how the theory of bias can further help to understand entrepreneurship.

\section{INTRODUCTION}

Most decisions that concern the minds and hearts of entrepreneurs are computationally intractable (Mitchell et al., 2007). Consequently the research on bias, which refers to the systematic deviation from rationality or norms in judgment and decision-making (c.f. Baron, 2007; Haselton et al. 2005; Tversky \& Kahneman, 1974), becomes relevant and interesting for entrepreneurship (Shepherd et al., 2015). The theory of biases provides a unique, practical, and empirically testable perspective on decision-making in entrepreneurship (Keh et al., 2002; Zacharakis \& Shepherd, 2001).

Research on biases in entrepreneurship (hereafter entrepreneurial bias) has increased rapidly since its inception and has become an important area for entrepreneurship (Krueger, 2005). Many individual papers on entrepreneurial bias have become foundational to the development of the entrepreneurship field to date. Two decades of research have demonstrated bias as a widespread phenomenon in entrepreneurship. As studies on entrepreneurial bias accumulate, a 
number of issues become critical, such as the consistency in definitions, the analysis of discrepancies among studies, and the overall direction of this stream of research. Scholars have pointed out the need to reveal, understand and resolve such issues, calling a review on entrepreneurial bias to advance this important area of research (Shepherd et al., 2015).

In order to generate cumulative progress and point to future directions, we assess the definitional issues, the relationships examined using biases, as well as the situations of entrepreneurial bias research in a context of other closely related research streams.

Entrepreneurial bias research has inherited from cognitive psychology a variety of definitions of biases with variations in both conceptualization and operationalization. For example, overconfidence has three distinct definitions (Moore \& Healy, 2008), which have been used interchangeably, even within a single article. The variations in definitions impede our accumulation of knowledge on entrepreneurial bias.

Scholars have examined a wide range of relationships between bias and other key constructs in entrepreneurship. This has led to a rich but somewhat disconnected body of research. To synthesize existing studies, we organize them by a typology of biases (Baron, 2007) as well as the consequences and antecedents of biases. Such organization not only facilitates the comprehension and synthesis of existing literature, but it also uncovers numerous tensions and equivocal findings. For instance, the empirical evidence does not corroborate the numerous theorizing efforts on how experience could increase or decrease certain biases.

Moreover, we situate entrepreneurial bias research in the context of the development of entrepreneurial cognition and emotion that took place after the second millennium (Mitchel, 2002; Cardon et al., 2012) and ongoing debates on bias in cognitive science (Stanovich, 2009; Tetlock \& Mellers, 2002). Situating entrepreneurial bias research into its related streams of 
inquiry sheds light on how we interpret bias in entrepreneurship and opens the door to further research. For example, how do we scholars view entrepreneurial biases? To date, the explanations of entrepreneurial biases often compete between the original theoretical definition of bias as errors (Tversky \& Kahneman, 1974) and the empirical ground that 'if biases are bad, how could biased entrepreneurs have created so many wonderful companies?'. Drawing from 'the great rationality debate' (Stanovich, 2009; Tetlock \& Mellers, 2002) and research on emotion and cognition, we posit that the interpretation of biases depends on the representations of individual entrepreneurial decisions as well as the extent of the match between decision ecologies and the evolutionarily adapted mechanisms that underlie the bias.

\section{BIAS AND ENTREPRENEURSHIP}

Bias refers to the systematic deviation from rational choice theory when people choose actions and estimate probabilities (Baron, 2007; Tversky \& Kahneman, 1974). The theory of bias has had enormous influence, resulting in the creation of new fields such as behavioral economics (Kahneman, 2003) and behavioral law (Jolls et al., 2000). The theory of bias is also transforming many fields - see reviews of biases in medical decision-making (Bornstein \& Emler, 2001), auditing (Solomon \& Trotman, 2003), accounting (Ashton \& Ashton, 1995), and public policy (Rachlinski, 2004).

Biases permeate decisions in entrepreneurship, and entrepreneurs display higher levels of bias than do managers in established organizations (Busenitz \& Barney, 1997). This can be due to various factors including, but not limited to, high uncertainty, information overload and velocity, a lack of historical information and organizational routines, and time pressure (Busenitz \& Barney, 1997; Baron, 2004; Hayward et al., 2006; Holcomb et al., 2009; Simon et al., 2000; Zacharakis \& Shepherd, 2001). Meanwhile, more biased decision-makers are more comfortable 
under ambiguous, uncertain and complex decision contexts (Gigerenzer \& Gaissmaier, 2011); consequently, they have an easier time making entrepreneurial decisions and are more likely to become entrepreneurs (Busenitz \& Barney, 1997; Busenitz \& Lau, 1996). Another influential group of decision makers in entrepreneurship, Venture Capitalists (VCs), are similarly biased in their new venture evaluation and investment decisions (Zacharakis \& Meyer, 2000; Zacharakis \& Shepherd, 2001).

\section{SEARCHING, SELECTING, AND CODING RESEARCH OF BIAS IN ENTREPRENEURSHIP}

Before assessing entrepreneurial bias research, to set the stage, we first lay out how we search, select and code the existing literature. Following the procedure of a systematic review (Tranfield et al., 2003), we searched literature from 1973 (the year bias research started in psychology) to January 1, 2014 for articles and analyzed their contents. The rest of this section documents this procedure.

\section{Searching for Articles}

To systematically locate the relevant articles, we integrated the approaches of Grégoire et al. (2011), Kiss et al. (2012) and Klotz et al. (2014) in a two-stage search process (see more details of the search process including the search algorithm in Appendix 1).

First, we scanned the top entrepreneurship and management journals in the Financial Times

journal list: Academy of Management Journal, Academy of Management Review, Academy of Management Perspectives, Entrepreneurship Theory and Practice, Journal of Business Venturing, Journal of International Business Studies, Journal of Management Studies, Management Science, Organization Science, Organization Studies, Organizational Behavior \& 
Human Decision Processes, with the addition of Strategic Entrepreneurship Journal (added by the authors).

Second, we checked the articles discovered in the first step to identify an inventory of biases to create an enhanced list of keywords. The keywords include entrepreneur, entrepreneurial, entrepreneurship, venture capital or venture capitalist and specific biases identified in the previous step, such as overconfidence and illusion of control. Appendix 1 contains the exact keywords used. Lastly, we searched the list of keywords in Scopus database, and found 286 published or in-press articles that contained the keywords.

It is possible that relevant articles may have escaped our sampling procedures despite the use of a large database (Scopus). There are two possible types of omissions: articles not written in English (because of the use of English keywords) and articles that either do not mention or use a different nomenclature for a particular bias in its abstract, title or keyword list. One example is Sandri et al. (2010), which studies status-quo bias but instead calls it 'psychological inertia'. This article has been added to our analysis thanks to a reviewer.

\section{Selecting and coding articles}

We further selected and coded the articles through a selection and coding process (Grégoire et al., 2011; Moroz \& Hindle, 2012) with the following questions in mind:

\section{Selection:}

1) Do the articles investigate decision-making in entrepreneurship?

2) Do the articles study biases as part of their central inquires, containing biases as representation, attributes, antecedents, or consequences in their theoretical models (Grégoire et al. 2011)?

\section{Coding:}

3) Who possesses the biases (entrepreneurs or VCs)?

4) What is the level of analysis?

5) What is the research method?

6) What are the independent and dependent variables, if they are distinguishable? 
7) What are the antecedents and consequences of entrepreneurial biases?

8) What are the findings and proposed future directions?

The first two questions aim to select articles that study biases as entrepreneurial phenomena instead of biases in general as in the field of psychology. To examine whether the articles study biases as part of their central inquires, we chose articles that developed specific propositions, hypotheses, and models using biases, regardless of their methodological approaches. Articles that did not develop models using biases are not included, such as those mentioning biases generally or using biases to discuss possible (non)findings.

This selection procedure resulted in 41 articles that study biases as part of their central inquiry in entrepreneurial decision-making. The selection used the two selection questions indicated previously and involved three raters, with a reliability rating of $95 \%$ based on intraclass correlation (ICC) (McGraw \& Wong, 1996). Table 1 lists all of these articles chronologically. A total of 32 are empirical papers, of which $18(56 \%)$ carried out surveys, eight (25\%) conducted (quasi) experiments (including conjoint analysis), three (9\%) held interviews, three $(9 \%)$ used a scenario technique in which respondents read hypothetical situations and stated their presumed behaviors or attitudes, two (6\%) employed case studies, and eight (25\%) analyzed secondary sources. As we did not limit our search based on methodology, we included also nine theoretical papers that developed specific propositions using biases (in italic in Table 1). As these theoretical papers do develop specific propositions, they are similar to the 'frontend' of empirical papers simply without empirical testing. The specific propositions, together with empirical papers, allow us to synthesize what the field has done on entrepreneurial bias and identify future opportunities. Lastly, we have not found any review articles on entrepreneurial bias to date. None of the conceptual or empirical papers to date has examined the body of entrepreneurial bias research in its entirety. 


\section{"Insert Table 1 here"}

Entrepreneurship literature has introduced eleven biases to explain entrepreneurship phenomena (Table 2). While most of these biases were investigated in just a single study, several biases have been studied repeatedly in a few articles. An examination of such studies reveals discrepancies in the conceptualization and operationalization of some of the most researched biases in entrepreneurship. Our assessment aims to examine the most prominent definitional issues in entrepreneurial bias research.

"Insert Table 2 here"

\section{DEFINITIONAL ISSUES}

The issue with overconfidence. Although overconfidence appears to be a clear and precisely defined concept on its surface, an analysis of 365 overconfidence papers by Moore and Healy (2008) uncovered three routinely muddled definitions of overconfidence: (1) over-estimation of one's actual performance, (2) over-placement of one's performance relative to others (betterthan-average effect), and (3) over-precision of one's beliefs in an analysis.

Studies of entrepreneurial biases have incorporated all three definitions to conceptualize and measure overconfidence. A single paper may use one definition to conceptualize and another to operationalize. For instance, eight empirical papers conceptualized overconfidence as overestimation, yet only three out of the eight papers measured overestimation accordingly (Simon \& Houghton, 2003; Simon \& Shrader, 2012; Zacharakis \& Shepherd, 2001). Instead, four of the eight papers measured overconfidence as over-precision (Busenitz, 1999; Busenitz \& Barney, 1997; Forbes, 2005; Simon et al., 2000), and one paper measured it as over-placement (Grichnik, 2008). 
Additionally, two concepts that may appear similar to overconfidence, confidence and entrepreneurial self-efficacy, often appear alongside overconfidence. Confidence denotes one's subjective certainty in his or her judgments, whereas overconfidence is the difference between one's subjective certainty and his or her objective accuracy (Busenitz, 1999; Gudmundsson \& Lechner, 2013). Thus, while distinct, the two concepts are clearly related to each other, and their relatedness draws the attention of entrepreneurship scholars.

Koellinger et al. (2007), empirically observing an excessive amount of confidence in entrepreneurs, reasoned that entrepreneurs must experience overconfidence and hence theoretically developed their study on the notion of overconfidence. In a paper about the confidence of entrepreneurs, Hayward et al. (2010) argued that more confident entrepreneurs are better able to cope emotionally, cognitively, socially and financially, and that these 'second order' benefits can potentially outweigh the negative consequences of overconfidence in entrepreneurs.

Hayward et al. (2010) theorized using task-specific confidence, which resembles selfefficacy. "The construct of self-efficacy differs from the colloquial term confidence." Confidence refers to strength of belief; nonetheless, it does not necessarily specify what the certainty is about. Self-efficacy denotes a belief in one's specific capabilities to generate specific attainment, and the concept of entrepreneurial self-efficacy is concerned with the self-efficacy of individuals in performing entrepreneurial decisions (Chen et al., 1998; Zhao et al., 2005). Forbes (2005) proposed that entrepreneurs with higher levels of entrepreneurial self-efficacy would be more overconfident; however, his test did not find the relationship to be significant. To capture taskspecific overconfidence in entrepreneurs, Simon \& Shrader (2012) developed a context-specific measure of overconfidence in entrepreneurship, or 'over self-efficacy'. 
The issue with overoptimism. The concept of overoptimism differs from but overlaps with overconfidence. Overoptimism (or overoptimism bias) refers to the notion that people overestimate the likelihood of positive events and underestimate the likelihood of negative events (Sharot, 2011). It overlaps with the over-estimation form of overconfidence in case of positive events only, but not in negative events. Another subtle but important difference is that while overconfidence is related to an individual's own capabilities and performance, and thus at least partially under the control of the individual, over-optimism can be completely detached from individual's own influence (e.g. I can be overoptimistic that my favorite sports team will beat the reigning world champion even if the odds are very low and I cannot influence this odd).

Due to the overlap between overoptimism and overconfidence, many studies on entrepreneurial overoptimism unsurprisingly drew on the overconfidence literature (Cassar, 2010; Lowe \& Ziedonis, 2006). Occasionally, the conceptualization of overoptimism can be very broad, where it does not specifically refer to positive events, thus blurring the distinction between overconfidence and overoptimism. For example, overoptimism was conceptualized as an overplacement of entrepreneurs' performance relative to that of others (Lowe \& Ziedonis, 2006), rendering it indistinguishable from the over-placement form of overconfidence.

In this section, we illustrate the most prominent issues in the conceptualization and operationalization of well-studied biases in entrepreneurship: overconfidence and overoptimism. The in-depth analysis of definitional issues is limited to these two particular biases, because a) their definitions are close to and can be confused with several other important concepts in entrepreneurship, and b) entrepreneurship literature has studied the two biases recurrently, but with varying conceptualization and operationalization. Such issues of inheriting conceptually and empirically distinct definitions and measures from cognitive sciences may not be limited to these 
two biases. Even though other biases have not been studied recurrently in entrepreneurship to show evidence of such issues, they may be prone to similar problems, which we scholars need to be cautious about. The good news is that mechanisms to distinguish and clean-up such issues in the field of psychology are underway, and have already begun to resolve inconsistent findings and long-standing theoretical arguments such as on overconfidence (Kwan et al., 2004). We believe future entrepreneurial bias research could benefit from doing the same. Otherwise, the variability in the definitions of closely-related concepts and the multitude of conceptualization and operationalization possibilities would greatly perplex and hinder the analysis, comparison, and synthesis of findings to accumulate and advance knowledge. At the very least, we entrepreneurship scholars need to be aware of the key definitional issues, which exist in the studies of biases in entrepreneurship and psychology, or fields with new concepts in general, in our effort to theorize and test relationships.

\section{KEY RELATIONSHIPS STUDIED USING BIAS}

Entrepreneurship literature has examined the relationships between biases and a diverse range of constructs including perception of risk, decision to start a venture, evaluation of opportunities, and evaluation of start-up teams (Franke et al., 2006; Keh et al., 2002; Simon et al., 2000). Overall, the relationships cluster around two themes: what factors do biases affect and what factors affect these biases? This pattern is comparable to the inputs-mediators-outcomes framework in reviews on many topics, e.g., new venture teams (Klotz et al., 2014), multimarket competition (Yu \& Cannella, 2012) and corporate social responsibility (Aguinis \& Glavas, 2012).

For the purpose of theoretical identification, we introduce a typology of biases (Baron, 2007). The typology organizes biases theoretically into three types based upon the mechanisms that they 
depart from normative models. To reflect these underlying mechanisms, we will name the three main types as: make-happy, sketchy-attribute, and psycho-physics and explain them one by one.

First, the 'make-happy' type includes biases that result from the effects of goals or desires on beliefs (Baron, 2007). People often adopt beliefs that make them happy or comfortable. For example, people selectively expose themselves to evidence and assimilate positive evidence, happily neglecting neutral or negative evidence, at least before they suffer the consequences of acting on these beliefs. The mechanism of this type of bias invokes not just cognition but also emotion, coinciding with the current surge of interest in entrepreneurial emotion research (Baron \& Tang, 2011; Baron, 2008; Cardon et al., 2012). Three biases of this type: overconfidence, overoptimism and self-attribution, have appeared in entrepreneurship literature.

Second, the 'sketchy-attribute' type of bias describes the behaviors of attending to one attribute when other attributes are more relevant (Baron, 2007). The attribute in question captures our attention because it is the result of recent or memorable events, it is a good indicator for another attribute in another context, or it is mistaken as a salient or useful indicator due to humans' limited capacity for information processing (Bless et al., 2004). These biases largely arise from cognitive mechanisms, and many biases of this type (such as availability, representativeness, the illusion of control, similarity, local bias, the law of small numbers, statusquo, and hindsight bias) are found in the entrepreneurship literature.

Third, the 'psycho-physics' type of bias refer to the distortion in our perception of quantitative attributes (Baron, 2007). Our sensitivity usually diminishes as intensity increases. The archetypal biases in this type include overweighting low probabilities (Kahneman \& Tversky, 1984) and framing effects for gains/losses (Levin et al., 2002). This type of bias is highly relevant to entrepreneurship, as will be discussed in subsequent sections. Nevertheless, 
our systematic search has not yielded studies on this type of bias in entrepreneurship literature to date, and there are many fascinating avenues of research that may be pursued.

We choose Baron's typology over other categorizations, such as Tversky and Kahneman (1974) and its updated version in Kahneman and Fredekerik (2002), because Baron's typology is based on how biases arise, different from other categorizations, which classify based on how biases are discovered, which is important for psychologists (Baron, 2007). In addition, the other categorizations cannot properly account for overconfidence bias, putting it into more than one category (Russo \& Schoemaker, 1992; Sánchez et al., 2011). The use of the typology of biases as well as their consequences and antecedents as a framework helps to identify the skeleton of the existing literature and to reveal possible tensions. Figure 1 (a and b) gives an overview of the existing relationships between bias and many other constructs in entrepreneurship. As the figure illustrates, the entrepreneurship literature includes a wide range of these relationships. Our goal is not to catalog the merit of all the individual relationships exhaustively, but instead to interweave and highlight where the literature gravitates, where theoretical and empirical tensions surface, and where interesting future research opportunities are high.

\section{"Insert Figure la and $1 b$ here"}

First, we will present the key issues in the consequences of each type of biases and then the issues in their antecedents. The presentation of consequences precedes that of antecedents because in general entrepreneurship literature first concerned with whether and how biases would matter in entrepreneurship, before pursuing the antecedents of the biases. Similarly to the definition issues we discussed, we will analyze key relationships in which tensions exist or possibilities to surface future research opportunities are high. Thus not all relationships or biases 
will be analyzed in the following section. When necessary, we also provide short in-section remarks to summarize the nuanced tensions or to point to specific future opportunities.

\section{'Make-Happy' Type of Bias}

\section{Consequences of Bias}

On risk-taking. Entrepreneurship requires a significant amount of risk-taking, and entrepreneurs display a greater amount of overconfidence and overoptimism than nonentrepreneurs (Busenitz \& Barney, 1997; Grichnik, 2008; Sánchez et al., 2011); therefore, scholars have attempted to use biases to explain entrepreneurial risk-taking. Scholars theorized that the biases of overconfidence and overoptimism make entrepreneurs overlook uncertainty and potential negative outcomes, thereby decreasing risk-perception and increasing risk-taking behaviors in new ventures (Cooper et al., 1989; Simon et al., 2000). However, the various attempts to test such reasoning have produced equivocal results to date.

Earlier studies uncovered that overconfidence empirically increased the likelihood of risky decisions, such as the decision to expand ventures (Mccarthy et al., 1993). Follow-up studies proposed that overconfidence would decrease risk perception (a mediator), thereby increasing new venture decisions (Simon et al., 2000) and boosted the evaluation of opportunities (Keh et al., 2002), however they were not empirically confirmed. Likewise, overoptimism failed to significantly explain entry decisions, - a key risky entrepreneurial decision (Lowe \& Ziedonis, 2006). Nevertheless, evidence from international entrepreneurship research using data from Germany and the US confirmed that overconfidence decreases risk perception and consequentially induces riskier behaviors and decisions of entrepreneurs (Grichnik, 2008). In addition, research confirmed the relationships between overconfidence and project-level risktaking behaviors, such as introducing riskier products (Simon \& Houghton, 2003). 
In a quasi-experiment, Wu and Knott (2006) separated the rational component of risk-taking behavior (to capture the real options values of risk-taking) and the irrational component of overconfidence. They found overconfidence to contribute to new business entry. However, in contrast, a later analytical study by Hogarth and Karelaia (2012) attribute the entry not to overconfidence or to any systematic bias, but instead to imperfect judgment.

Meanwhile, conceptually scholars continued to use overconfidence to develop theories of entrepreneurial risk-taking. For instance, Hayward et al. (2006) developed a well-recognized hubris theory proposing that more overconfident entrepreneurs display risky behaviors, such as starting ventures with fewer resources but committing greater resources of their own, underestimating the need for key resources, but overestimating their own abilities.

In summary, despite strong theorizing effort, research exploring the impact of bias on risktaking has not yet amassed a consistent empirical foundation on which to build strong conclusions. The inconclusive relationships could be due to situational factors, as suggested by Grichnik (2008). Future research could dive deeper into person-situation interactionist models to identify specific situational factors that could interact with overconfidence to trigger risk-taking.

On performance measures. Overconfidence and overoptimism carry both positive and negative effects on performance; however, their positive effects and negative effect are due to distinct theoretical reasons.

The negative effects of overconfidence and overoptimism gain their theoretical foundation directly from the classical heuristics and bias research program, which originally deemed biases as systematic errors in decision-making (Kahneman \& Tversky, 1996). If biases are errors, researchers in entrepreneurship consequently become interested in whether biases in entrepreneurial decisions impact new venture performance. Theoretical studies have argued that 
overconfidence leads to underestimation of competitive response or overestimation of demand. The inappropriate estimations in turn generate riskier and less successful outcomes (Simon \& Houghton, 2002). For instance, Hayward et al. (2006) reasoned that overconfident founders maintain low liquidity, which increases the likelihood of failure. This line of reasoning is also in line with evidence in many industries that involve high risk-taking, such as banking and market entry, where greater overconfidence causes failures (Wu \& Knott, 2006; Camerer \& Lovallo 1999).

Empirical evidence in entrepreneurship confirmed that overoptimism prolongs entrepreneurs' unsuccessful development efforts, resulting in wasted resources, lower levels of employment and reduced revenues (Lowe \& Ziedonis, 2006). In addition, overconfident entrepreneurs tend to underestimate competition, under-resource their ventures, rely less on external networks for relational resources, and introduce riskier products. All of these behaviors lower the likelihood of their ventures' survival (Gudmundsson \& Lechner, 2013; Koellinger et al., 2007).

The positive effects of biases get their support primarily from theories on fast-and-frugal decision-making as well as theories on emotions. Motivational theories reason that overconfidence and overoptimism increase the motivation to initiate entrepreneurial action (Cassar, 2010; Simon \& Shrader, 2012), heighten resilience and work effort, and help to cope with setbacks and failures during the entrepreneurial processes (Hayward et al., 2010). Overconfidence and overoptimism induce higher ability and outcome expectations, thereby enhancing performance (Van Eerde \& Thierry, 1996). The interpretations of these biases will be further discussed later. 


\section{Antecedents of Bias}

The role of experience. Past experiences in part influence human behaviors (Winter \& Nelson, 1982). More experienced decision-makers rely more on intuition, thereby developing a sense of security and confidence that could potentially be unfounded (Macmillan et al., 1987). Following these theories, entrepreneurship scholars proposed various relationships between experience and bias but yielded inconclusive results. First, Zacharakis and Shepherd (2001) proposed a positive correlation between experience and overconfidence in VCs, but did not find it to be empirically significant. In another study using conjoint analysis, Shepherd et al. (2003) discovered that as the experience of VCs increased, their decision accuracy at first grew and then decreased after an optimal level of 14 years; their explanation is that VCs become more overconfident as they age. In a complementary vein, Hayward et al. (2006) proposed that entrepreneurs with prior experience in founding successful ventures become more overconfident, despite the fact that their new ventures differ from their previous ones.

Such reasoning is rejected by empirical results that younger entrepreneurs were more overconfident than older entrepreneurs (Forbes, 2005) and nascent entrepreneurs were more confident in their skills, knowledge, and experience than serial entrepreneurs (Koellinger et al., 2007). Forbes explained that older managers were less overconfident because they sought more information and took longer to make a decision than did younger managers (Taylor, 1975).

On the surface, the results of Forbes (2005) and Koellinger et al. (2007) seem to largely refute prior theoretical developments (Shepherd et al., 2003; Hayward et al., 2006). However, experience is a complex concept (Shepherd et al., 2003) that could mean many different things such as the number of past ventures, the number of successful ventures, years of business experience, or even age. In addition, one needs to consider the quality of the experience, e.g. 
whether positive or negative. The roles of the decision makers (entrepreneurs, VCs, students in entrepreneurship programs, etc.) and the context of each experience could also matter. Therefore, the relationships between experiences and biases are inconclusive at best and offer an interesting avenue for further research at both between-person and within-person levels. An alternative direction is to investigate not only experience as an antecedent of overconfidence but also the interaction effect of experience and overconfidence on decision quality or performance.

The easiness/difficulty of decision tasks. The difficulty of a decision affects overconfidence in an interesting manner. When a task is easy, people choose to enter markets overconfidently because they believe that they are better than average (over-placement); when a task is difficult, they become under-confident about entering because they believe they are worse than average (under-placement) (Moore \& Cain, 2007). On the contrary, in the case of another form of overconfidence, overestimation, people overestimate their performance when tasks are difficult and underestimate their performance when tasks are easy (Moore, 2008). Therefore the difficulty of decision task influences over-placement and overestimation in opposite ways.

Interestingly, many factors that could increase the difficulty of decision tasks have been proposed to positively correlate with overconfidence, such as environmental complexity and environmental dynamism (Hayward et al., 2006; Simon \& Shrader, 2012), the riskiness of the contexts (Simon \& Houghton, 2003), unfamiliar contexts (Zacharakis \& Shepherd, 2001), pioneering of product introduction, and the hostility of the environment (Simon \& Shrader, 2012). All these proposed relationships were supported by empirical evidence, except for environmental dynamism, which was negatively correlated with overconfidence in a sample of 55 owners of small computer companies (Simon \& Shrader, 2012). 
We need to note that all aforementioned relationships between contextual factors and overconfidence in entrepreneurship treat overconfidence exclusively as 'overestimation' (Simon \& Houghton, 2003; Zacharakis \& Shepherd, 2001; Simon \& Shrader, 2012; Hayward et al., 2006). These contextual factors complicate decisions and increase the difficulty of decisionmaking; thus, they should increase overestimation and decrease over-placement. It can be interesting for management scholars to study also over-placement in situations of varying difficulty of decision tasks. It can also be important to formally examine how task difficulty might mediate the relationships between contextual factors and overconfidence.

The role of (dis)trust. Trust creates confident expectations, rendering the trusting party more comfortable about ambiguous or unclear situations (Rousseau et al., 1998). Along this line of logic, entrepreneurship research has proposed that the trust the entrepreneurs have in their networks increases overconfidence (De Carolis \& Saparito, 2006).

Subsequently, Gudmundsson and Lechner (2013) revealed empirically that distrust (negative expectations in others) was positively associated with overconfidence. They reasoned that a distrusting entrepreneur would be reluctant to delegate tasks to or seek assistance from others (Gino \& Moore, 2007), behaviors that could intensify miscalibration and lead to overconfidence. The contrasting relationships between (dis)trust and overconfidence in De Carolis and Saparito (2006) and Gudmundsson and Lechner (2013) appear to be a paradox. Still, while many studies equate distrust with lack of trust, treating them as opposites (Gans et al., 2001; Omodei \& McLennan, 2000; Ziegler \& Lausen, 2005), neuroscience evidence considers trust and distrust distinct phenomena (Dimoka, 2010): trust deals with positive expectations about the trustee's beneficial conduct, and distrust deals with negative expectations about the trustee's harmful conduct (Cho, 2006; Xiao \& Benbasat, 2003). Trust and distrust should bear different 
relationships with their antecedents and effects (Lee \& Huynh, 2005). Thus, future research awaits to disentangle the relationships between trust, distrust and bias. An additional research opportunity is to study this relationship in the reverse direction, i.e. how overconfidence and overoptimism might influence trust or distrust, because more biased entrepreneurs might be more prone to trust or distrust others.

\section{'Sketchy-Attribute' Type of Biases}

\section{Consequences of Bias}

On risk-taking. Similarly to the 'Make-Happy' biases, scholars pay significant efforts to investigate how 'Sketchy-Attribute' biases influence risk-taking (see Figure 1b), theorizing that biases decrease the perception of uncertainty and thus increase risk-taking behaviors. Empirically, the various attempts to test such reasoning have thus far yielded inconclusive results. Simon et al. (2000) found that the biases of illusion of control and the law of small numbers decreased individuals' perceptions of the riskiness of new ventures and hence increased new venture decisions. Simon et al. (2000) also proposed risk perception to fully mediate the relationships, but empirically the mediation turned out to be partial.

Building on research by Simon et al. (2000), Keh et al. (2002) studied the evaluation of opportunities instead of new venture decisions as the outcome variable in their models, and empirically found that risk perception fully moderates the relationship between the illusion of control and the evaluation of opportunities. Furthermore, Keh et al. also found that the law of small numbers had a direct effect on opportunity evaluation without the mediation of risk perception.

Building upon these findings, De Carolis and Saparito (2006) developed a conceptual model in which the illusion of control and representativeness decrease risk perception, thereby leading 
to the exploitation of entrepreneurial opportunities. Part of the model was later tested and confirmed; illusion of control and risk propensity were found to positively correlate with the progress of a new venture (De Carolis et al., 2009).

Barbosa and Fayolle (2010) further extended the model to include an availability bias. The availability of new information expressed in negative (positive) terms was found to increase (decrease) the perceived risk associated with a new venture, thus reducing (increasing) individuals' willingness to start the venture.

On performance. Biases of the sketchy-attribute type have important implications on performance, since these biases originally denote errors in decision-making (Tversky \& Kahneman, 1974). However, few researchers have examined these effects. To date, only the illusion of control has been linked to performance-related measures. Carr \& Blettner (2010), citing evidence that bankers with greater illusions of control obtained worse trading results, tested the hypothesis that illusion of control lowers the performance of entrepreneurs in their decision-making. Similarly, De Carolis et al. (2009) found illusion of control to be positively correlated with new venture progress - a performance related measure. This stream of research is still incipient, with few articles largely disconnected from one another. Studies examining the performance implications of these biases need further development by assessing multiple and more direct performance indicators such as new venture survival and returns under uncertainty.

On new venture evaluation. Similarities between VCs and entrepreneurs, in demographic factors, work value congruence, and perceived power equality, were proposed to positively bias VCs' willingness to invest (Cable \& Shane, 1997). Empirically, VCs evaluate more positively new ventures founded by entrepreneurs who have similar type of education and previous 
working experience (Franke et al., 2006) or similar process and nature of decision-making (Murnieks et al., 2011).

\section{Antecedents of Bias}

Social capital. The social networks of entrepreneurs matter for biases. For instance, the structural holes in an entrepreneur's network enable access to various information sources, increasing the entrepreneur's beliefs about his or her knowledge base (Cohen \& Levinthal, 1990). Adopting network theory on social capital, De Carolis and Saparito (2006) proposed that these structural holes could predict illusion of control and that the strength of network ties could predict representativeness bias. Later, De Carolis et al. (2009) theorized and empirically confirmed that the extent of an entrepreneur's social network and personal capital would enhance shared attitudes and mental models, which in turn would increase illusion of control. This line of study between network positions and entrepreneurial behaviors has enormous potential, because virtual entrepreneurship on social networks has been growing exponentially. Virtual entrepreneurs on a virtual social network "second life" in 2009 alone earned US\$55 million (Rosenwald, 2010). Virtual social networks contain 'big data', opening unprecedented new research opportunities in social, behavioral, and economic sciences (Bainbridge, 2007).

Looking through the literature, studies on the sketchy-attribute type of biases have produced fewer discrepancies and inconclusive results than have studies on make-happy type of biases, and this could be due to two reasons. First, the studies of sketchy-attribute biases are highly fragmented and disconnected to one another, thus having less opportunity to yield contrasting results (See Figure 1b for six different antecedents studied in the social capital theme alone). Second, biases in the sketchy-attribute do not carry as much emotional and motivational implications as the biases in 'make-happy' do, and therefore the relationships are less complex. 


\section{'Psycho-physics' Type of Biases}

Our search did not yield any research that studied biases of this type, and we believe that this represents a key gap for future research. We will use two short examples to illustrate the importance of research on psycho-physics type of biases.

The psycho-physics bias describes a distorted perception of probability in which one underestimates medium and high probabilities and overestimates lower probabilities (Kahneman \& Tversky, 1979). Given the low probability of success of many entrepreneurial projects, especially those involving new and risky technology, future studies could describe whether entrepreneurs' perceptions of new venture success are biased differently across ventures with different likelihoods of success (e.g. $0.001 \%$ vs. $0.1 \%$ vs. $10 \%$ vs. $50 \%$ ).

Another instance of bias occurs when people perceive the difference between a prize of $\$ 10$ and $\$ 20$ subjectively to be larger than the difference between $\$ 1,010$ and $\$ 1,020$ (Baron, 2007). In entrepreneurship, we could ask "is there a difference in perception between a VC investing \$1 million or $\$ 1.1$ million in a start-up versus 0.1 million or 0.2 million? What is the impact of this difference?"

Entrepreneurship deals with numbers often in a manner of nested real options that are nonintuitive and often exceed the bounded rationality of decision makers (McGrath \& Desai, 2010; Zhang \& Babovic, 2011), thus the 'psycho-physics' type of biases, i.e. the study of the distortion in entrepreneurs' perception of quantitative attributes, can be highly pertinent and a potentially rich source of future study.

\section{Future Research Recommendations on Using Biases to Study Relationships}

In assessing the biases and the relationships studied, we realized the paramount need to pay attention to even highly nuanced differences in defining biases. The inconsistent findings on 
relationships to date, as reviewed above, could be in part due to high variation in the conceptualization and operationalization of biases. Prior research has often attributed empirical non-findings to measurement issues (e.g. Keh et al., 2002). Adopting precise and consistent definitions and measures may not only help resolve the outstanding controversies, but can also facilitate possible future meta-analysis and the inclusion of moderators to push forward finer models of the entrepreneurial phenomena using bias theory. As yet a vast majority of studies have limited themselves to the examination of direct effects. Few have studied the interactions between biases and other factors, such as risk perception (Grichnik, 2008; Keh et al., 2002; Simon et al., 2000) and prior experience (Carr \& Blettner, 2010). Of additional interest is the possibility of nonlinear effects (e.g. Shepherd et al., 2003) to gain a more nuanced understanding.

To yield finer models, multilevel analysis in entrepreneurial decision-making presents a promising opportunity for future research (Shepherd, 2010). Multilevel studies can potentially reveal the biases of teams and biases of entrepreneurs in teams to reflect on how recursively biases operate within a team and feedback on those biases. This topic is very pertinent because teams, rather than individuals, make many entrepreneurial decisions, yet to date almost all studies on entrepreneurial biases are at the individual level (see Gudmundsson \& Lechner (2013) for a rare exception). Future research may explore if and how team-based decision-making is biased and may also address how individual biases impact team decision-making. Future research should also examine how making decisions in a team may alter the biases of individuals; for example, individuals may exhibit different biases or different degrees of bias when making decisions in a team, versus making them alone.

Such multi-level research can also untangle the impact of cultural contexts. Existing research has examined several country settings outside of the US, including Singapore (Keh et al., 2002), 
Australia (Shepherd et al., 2003), Austria (Franke et al., 2006), Germany (Burmeister \& Schade, 2007; Franke et al., 2006; Grichnik, 2008), the Netherlands (Ebbers \& Wijnberg, 2012), and Iceland (Gudmundsson \& Lechner, 2013). These studies provide insights into the generalizability of findings across cultural and national borders. Future research could include international samples in their designs, as in Koellinger et al. (2007), who found that while biased perceptions had a crucial impact on new business creation across eighteen countries, people of certain cultures have a more natural tendency towards overconfidence than others. Similarly studies in cognitive sciences have reported persistent cross-cultural variations in overconfidence: for instance, people of Chinese culture on average are more overconfident (Yates et al 1997; Yates et al 1998). Cultural and institutional differences could moderate the relationships between biases and other entrepreneurial constructs.

Lastly, future research design on entrepreneurial biases may consider theorizing and measuring uncertainty, not just risk. When confronting risk, decision makers know the probabilities of all outcomes for all alternatives; however, when confronting uncertainty, probabilities are unknown or unknowable (Knight, 1921), which more appropriately reflect the decisions in entrepreneurship (Baron, 1998; Busenitz \& Barney, 1997). On a neurological level, decision-making under risk differs from decision-making under uncertainty (Volz \& Gigerenzer, 2012). Thus, entrepreneurial bias literature should adopt uncertainty in addition to risk.

\section{SITUATING ENTREPRENEURIAL BIAS RESEARCH}

Thirty years after the publication of the first article on bias (Tversky \& Kahneman, 1974), the bias research program has progressed greatly in cognitive sciences; moreover, entrepreneurship as a field meanwhile has prospered and advanced on many fronts. In this section, we attempt to situate entrepreneurial bias research in the context of the research streams developed subsequent 
to the original publication of bias, such as entrepreneurial cognition (Mitchell et al., 2002), entrepreneurial emotions (Cardon et al., 2012), the 'great rationality debate' (Stanovich, 2009; Tetlock \& Mellers, 2002), and studies of biases in other fields. These streams of research have either taken off lately or have made substantial new development, holding fundamental implications for entrepreneurial bias research.

\section{The Tie to Entrepreneurial Cognition Research}

Entrepreneurial bias research started as one of the first works on entrepreneurial cognition in the mid-1990s (Bird, 1992; Busenitz \& Lau, 1996; Mitchell et al., 2002). Entrepreneurial bias research much exemplifies entrepreneurial cognition research in general, which aims to understand how entrepreneurs consciously or subconsciously reject elaborate and complex decision-making procedures (Mitchell et al., 2007).

Bias, along with heuristic, intelligence and knowledge, are some of the most studied themes in cognitive psychology that can lend themselves easily to the studies of entrepreneurship (Frese, 2009; Frese \& Gielnik, 2014). Heuristic, intelligence and knowledge all have inherent connections with bias.

Heuristics refer to simplifying shortcuts or principles that people use for problem solving and information processing (Baron, 2007; Kahneman \& Tversky, 1982; Wilcox, 2011). Thus heuristics are fast-and-frugal, freeing people from making a complete and systematic processing of information, which can often be impossible in entrepreneurship or management in general (Manimala 1992; Bingham \& Eisenhardt, 2001). Because heuristics simplify information processing, they are associated with biases: systematic departures from the normative rational theory (Kahneman \& Tversky, 1982; Gilovich et al 2002). However the implications of many heuristics in entrepreneurship, such as those discovered early on (Manimala 1992), on biases are 
unknown. Moreover, effectuation, a new theory in entrepreneurship, suggests that entrepreneurs use a set of heuristics to make decisions (Sarasvathy, 2001), and the relationships between these effectual heuristics and biases warrant theoretical discrimination and empirical identification. For example, intelligence correlates with the tendency to avoid some biases but not some others (Stanovich \& West, 2008), yet to date, intelligence has been missing either as an antecedent or as a moderator in studies of entrepreneurial biases. Knowledge, especially "highly developed, sequentially ordered knowledge" known as entrepreneurial expert script, can bias entrepreneurs towards commitment engagement (Mitchell et al., 2000; Smith et al., 2009) and hence have important implications for entrepreneurial bias research (Mitchell et al., 2008).

In short, the study of biases has evolved to be a pillar of entrepreneurial cognition research, yet biases are not just cognitive phenomena; they also have roots in emotions.

\section{Affect Matters, Especially For 'Make-Happy' Type of Biases}

In folk decision analysis, emotion appears antithetical to rationality (Haidt, 2001); thus, unbiased thinking necessitates the eradication of the influences of emotion. In scientific studies on affect, which includes emotion, moods, and feelings, the absence of critical biases such as overoptimism leads to depression and anxiety, and the presence of overoptimism benefits physical health and is linked to greater activation (Sharot, 2011). Overconfidence produces a crucial byproduct, positive affect (Armor \& Taylor, 2002; Lyubomirsky et al., 2005).

The role of affect in bias is particularly relevant to the make-happy biases. These make-happy biases arise not because people take inappropriate attributes (sketchy-attribute type), or distort large or negative numbers (psycho-physics type), but precisely because they produce positive affective benefits. Make-happy type of biases reduce anxiety and depression and increase action (Sharot, 2011). The benefits of positive affect due to the bias may compensate for short-term loss 
in certain cases. Shepherd et al. (2009), in a similar vein, reasoned that many entrepreneurs do not immediately drop failed projects despite financial costs so as to better adjust their emotions for subsequent entrepreneurial actions.

Due to the mechanisms underlying the make-happy type of biases, affect has critical implications. While biases of this type could result in less optimal short-term decisions, the affective benefits could lead to better well-being and performance outcomes (Puri \& Robinson, 2007). Future studies of the make-happy biases should examine these biases not only as cognitive phenomena but also as affective ones.

For sketchy-attribute type of biases, their mechanisms are primarily cognitive, and thus their relationships with affect are less direct and obvious. Even so, they still have indirect but fundamental connections with affect. First, emotions have adaptive regulatory effects on cognition that can facilitate or impede rationality (Stanovich, 2009) through the appraisal dimensions of affect (Foo, 2011). Furthermore, valence and activation theories posit that affect carries directive properties that influence cognition. For example, positive affect (such as joy) relates to the broadening of psychological processes, such as divergent thinking (Fredrickson, 2001). Negative affect (such as sadness) in contrast leads to the narrowing of attention and to activities that promote self-preservation (Clore et al., 1994). The activation function of emotions also impact cognition, as high activating emotions (such as excitement or anger) also correlate with the narrowing of psychological processes (Harmon-Jones \& Gable, 2008). Whereas low activating emotions (such as relaxation or despondency) broaden psychological processes, leading to diffuse attention (such as detachment) (Gable \& Harmon-Jones, 2010).

In the reverse direction, biases could influence the appraisal and therefore alter emotion. For instance, entrepreneurs can be overconfident in their appraisal of venture progress, judging a 
setback in the eyes of a rational decision-maker as a normal pace of progress, and as a consequence the entrepreneurs will feel less negative emotions.

Since research has shown that emotions and biases both influence risk perception, entrepreneurial behaviors, and opportunity evaluation (Foo, 2011; Hahn et al., 2012; Podoynitsyna et al., 2012), the interactions between cognitive biases and affect on entrepreneurial actions offer potentially interesting new lines of inquiry (Foo, 2011).

In conclusion, various theories agree that affect influences heuristics and biases (e.g., Baron, 2007; Mackie \& Worth, 1989; Park \& Banaji, 2000), and thus research on entrepreneurial behavior and decision-making should not separate cognition from affect, another emerging stream of research in entrepreneurship (Baron, 2008; Foo et al., 2009; Foo, 2011; Shepherd et al., 2009; Cardon et al., 2012).

\section{Do We Interpret Biases As Bad Or Good? - The 'Great Rationality Debate'}

As entrepreneurship scholars follow the path of cognitive scientists in documenting numerous biases and analyzing them, it is worthwhile to note that cognitive scientists have since started a huge debate about the interpretation of biases as decision errors.

Some scholars in cognitive sciences lament the pessimistic view of biases as errors and instead advocate biased decision-making as fast-and-frugal and well performing (Goldstein \& Gigerenzer, 2002). New evidence suggests that biased decision-making, which relies on few cues and ignores most accessible information (e.g., recognition heuristic and "take-the-best"), leads to accurate judgments (Bröder \& Eichler, 2006; Goldstein \& Gigerenzer, 2002; Rieskamp \& Otto, 2006; Todd \& Gigerenzer, 2003, 2007).

Scholars reason that biased decision-making is a product of evolution: while it does not work well in artificial settings (such as working with probabilities), it is well-adapted to tackle 
naturalistic decisions under constraints of time, knowledge, and computational capacity (Rieskamp \& Hoffrage, 2008). As a consequence, cognitive biases have a beneficial evolutionary explanation and are not simply errors (see chapter 4 of Brase et al., 1998; Cosmides, 1996; Rode et al., 1999).

The academic debate on how much irrationality to attribute to human cognition has been so intensive and fundamental that cognitive scientists named it 'the great rationality debate' (Cohen, 1981; Gigerenzer, 1996; Kahneman \& Tversky, 1996; Stanovich, 1999; Stein, 1996; Winterfeldt \& Edwards, 1986).

To date, the 'great rationality debate' has largely not propagated to entrepreneurship research. Other than the notable exception of Bryant (2007) that takes a positive stance towards bias using the ecological approaches to decision making, the majority of entrepreneurial bias studies explicitly or implicitly adopt the classical view of bias by Kahneman (1973). Studies adopting this view have examined the negative connotations of biases, such as on inadequate estimation of demand and competition (Simon \& Houghton, 2002), and poor decision quality of entrepreneurs (Carr \& Blettner, 2010) and VCs (Zacharakis \& Shepherd, 2001). Nevertheless many papers on entrepreneurial bias have also discussed the possible benefits of biases (c.f. Cable \& Shane, 1997; Coval \& Moskowitz, 1999; Cumming \& Dai, 2010; Sandri et al., 2010).

\section{What Does The 'Great Rationality Debate’ Mean To Entrepreneurship Research?}

To examine better the pros and cons of bias in entrepreneurial decision-making, we think that it is timely to bring the 'great rationality debate' to the entrepreneurship field. The two camps of the 'great rationality debate' differ on two fundamental issues: decision ecology and decision representation. 
Decision ecology matters - whether biased decision-making serves us well depends on the ecology of the decision. In situations where the decision ecology and ancient evolutionary ecology overlap, biased decision-making tends to work. For example, the general public performed equally as well as experts in predicting the winners of 2003 men's Wimbledon tennis tournament, even though the public adopted just one simple recognition heuristic: predict the player whose name you recognize more than the others. The same recognition heuristic however, when used in situations where the decision ecology is different, such as to choose financial services, overwhelmingly underperforms (Bazerman, 2001).

While our brain has evolved to make fast and frugal decisions for survival across the Pleistocene environment, at times our brain may be maladaptive in the modern world decisions. The key challenge is to identify the relevant ecology for each particular decision, in our case, each decision that entrepreneurs make in the contemporary world. For decisions that require entrepreneurs to work effectively with technological acceleration, network externality, virtual environments, a failure-tolerating culture, or optionality in venture growth, for instance, the ability to override our natural fast-and-frugal responses takes on great importance (Einhorn \& Hogarth, 1981). In situations that require entrepreneurs to perform tasks that humans have been doing relatively consistently since Pleistocene era, such as building relationships, leading teams, or understanding customers, some of the biased fast-and-frugal decision-making could still serve us exceptionally well.

Decision representations matter too. Many experiments in cognitive science show that if the decisions are represented "in a format that meshes with the way people naturally think about probability, they can be remarkably accurate" (Pinker, 1997, p. 351). 
We need to be cautious about the extent to which the representation of our current world meshes with our evolutionarily designed cognitive mechanisms. For example, while psychologists show that representing probability as frequency can eliminate bias, probability still abounds because it allows better algorithmic and statistical operations. The representations of information in many new venture decisions do not correspond with how homo sapiens' brains naturally respond. This discord between information representation and one's natural response may happen when entrepreneurs try to compare deals from VCs and banks, decide whether to develop or buy a technology, or securitize the footnote of legal documents of foreign suppliers. The modern world presents many abstract and non-naturalistic decision environments, which require us to override the natural representations that first take place.

However, the natural representations still function well enough for us to accurately discern faces, infer the intentions of others, and carry out many other computationally-heavy tasks without expending much cognitive effort. For countless tasks, our naturalistic representations perform at a level that the best artificial intelligence software today can only envy.

In summary, the performance of biased decision-making depends on decision ecologies and representations. Thus, the extent of the match between evolutionarily-adapted mechanisms and the representations called for in entrepreneurial decision situations, become essentially the puzzle which entrepreneurship research should seek to untangle.

\section{In Light of the Study of Bias in Other Fields}

Many other fields have similarly reviewed biases in decision-making in their respective flagship journals, such as medical decision-making (Bornstein \& Emler, 2001; Elstein et al., 2002), jurisdiction (Langevoort, 1998), behavioral auditing (Shanteau, 1989), behavioral economics (Kahneman, 2003), and public governance (Rachlinski, 2004). Comparing the studies 
of bias in those fields with ours in entrepreneurship, we identified the issue of debiasing (Pronin et al., 2002) to be notably missing in entrepreneurship research as well as management research in general (Milkman et al., 2009).

Simple cognitively effortful debiasing attempts can actually exacerbate bias, and such alleviating of bias involves cognitive and emotional capabilities (Hodgkinson \& Healey, 2011). Often, biases can be altered instead by variation of setting, accessibility of content, experiences (Sanna \& Schwarz, 2003), and entrepreneurial approaches such as effectuation and causation (Zhang et al., 2014). Decision aids, from simple checklists to expert systems, are popular debiasing tools for a wide range of applications such as health treatments, screening decisions (O'Connor et al., 1999; Stacey et al., 2011), and risk communication (O’Connor et al., 2003). In fact, practitioners of entrepreneurship do use decision aids in many forms. For example, VCs often use spreadsheets or evaluation forms containing lists of criteria to facilitate the systematic evaluation of new projects (Petty \& Gruber, 2011). Many entrepreneurs use the Business Model Canvas to avoid omitting important aspects of business models. Studying the effects of decision aids on bias could be relevant and valuable for practitioning communities.

Lastly, other fields such as finance and marketing have studied some biases that have yet to appear in entrepreneurship literature but could heavily shape the future of entrepreneurship research. For instance, the base rate fallacy, which describes the tendency to ignore base rate information and instead focus on specific information (Baron, 1994), and irrational escalation, a phenomenon by which people justify increased investment in a decision based on the cumulative prior investment and despite new evidence suggesting that the decision was probably wrong, could happen in new venture evaluation. Table 3 lists a number of biases unstudied to date for future research considerations. 
"Insert table 3"

\section{DISCUSSION AND CONCLUSION}

Scholars have used the theory of bias to study various decision-making phenomena in entrepreneurship. While this body of research has yielded many interesting insights, it also is ridden with definitional disagreements, equivocal relationships, and overdue connections to advancements in other relevant research streams. In order to generate cumulative progress, we have critically examined this body of research and unveiled a range of interesting issues and future research opportunities.

Definitional disagreements are normally expected during the initial phase of new and important theories (Gladwin et al., 1995), but should be subsequently resolved both conceptually and operationally. Equivocal results signal the formation of certain initial common grounds of interest and suggest clear avenues for future research to reach convergence or breakthroughs. Moreover, it is beneficial to keep an eye on relevant adjacent research fields and leverage their new development to further the study of bias in entrepreneurship. In this regard, advances in cognitive sciences are particularly important in furthering theoretical development. For instance, entrepreneurship scholars have accumulated significant evidence both for and against biased decision-making in entrepreneurship. However, underlying such descriptive evidence, parsimonious and general theoretical explanations have not been easy to construct. This is clearly an area that can greatly benefit from stronger ties to the research of biases in cognitive sciences. Since the first article on biases (Tversky \& Kahneman, 1973), significant progress has been made with respect to the pros and cons of biases, i.e. the 'great rationality debate'. And we have pinpointed the exact connections that entrepreneurial bias research can make to benefit from nearby fields. 
This study has made a number of contributions. First, this research answers the call by Shepherd et al. (2015) to provide the first critical examination of the studies of biases in entrepreneurship, carefully documenting discrepancies and dissonances in the literature to facilitate future cumulative progress. Second, in order to examine this body of literature, a structure by a typology of bias and input-mediator-output framework has been devised. This structure helps not only to unveil the tensions and opportunities for further research, but also to organize this growing body of research going forward. Third, we argue that the studies of bias in entrepreneurship could benefit from adjacent fields, such as the study of affect, as well as the rapid and exciting advances on biases in cognitive sciences. For instance, the implications of 'the great rationality debate' on entrepreneurship have been specifically examined in this text. Lastly, this article can serve as a synthesized base for future research theorizing using biases in entrepreneurship.

Bias has provided a captivating lens to study behavioral decision-making in entrepreneurship for the more than 20 years. This paper attempts to deliver an assessment and reflection on these studies: on the definitions of biases, the relationships studied, and the broader contexts. The 20 years of progress, as synthesized, generate even more fundamental and intriguing questions, both theoretical and empirical. We conclude by summarizing the most important future research opportunities (Table 4).

\section{"Insert table 4"}

These opportunities are only a partial list, as we continue realizing the potential of using bias as a theoretical lens through which to study entrepreneurship. By now, not only has bias occupied a central place in a complex net of entrepreneurial phenomena, but its theoretical foundation in cognitive sciences is also being reshaped actively. Thus the study of bias in 
entrepreneurship is an intellectually fruitful endeavor that could help shape the future of our scholarships of entrepreneurship.

\section{APPENDIX \\ "Insert Table 5" \\ REFERENCES}

Aguinis, H., \& Glavas, A. (2012). What we know and don't know about corporate social responsibility: A review and research agenda. Journal of Management, 38(4), 932-968.

Armor, D. A., \& Taylor, S. E. (2002). When predictions fail: The dilemma of unrealistic optimism. In T. Gilovich, D. Griffin, \& D. Kahneman (Eds.), Heuristics and biases: The psychology of intuitive judgment. (pp. 334-347). New York, NY: Cambridge University Press.

Ashton, R. H., \& Ashton, A. H. (1995). Perspectives on judgment and decision-making research in accouting and auditing. In R. H. Ashton \& A. H. Ashton (Eds.), Judgment and decision-making research in accounting and auditing (pp. 3-28). Cambrige, UK: Cambridge University Press.

Bainbridge, W. S. (2007). The scientific research potential of virtual worlds. Science, 317(5837), 472-476.

Barbosa, S. D., \& Fayolle, A. (2010). Revisiting entrepreneurial risk taking: Combined effects of cognitive heuristics. Academy of Management Annual Meeting Proceedings, 8(1), 1-6.

Baron, J. (1994). Thinking and deciding (2nd ed.). Cambrige, UK: Cambridge University Press.

Baron, J. (2007). The study of thinking. In J. Baron (Ed.), Thinking and deciding (4th ed., pp. 54-58). Cambrige, UK: Cambridge University Press.

Baron, R. A. (1998). Cognitive mechanisms in entrepreneurship. Journal of Business Venturing, 13(4), 275-294.

Baron, R. A. (2004). The cognitive perspective: A valuable tool for answering entrepreneurship's basic "why" questions. Journal of Business Venturing, 19(2), 221-239.

Baron, R. A. (2007). Behavioral and cognitive factors in entrepreneurship: Entrepreneurs as the active element in new venture creation. Strategic Entrepreneurship Journal, 1(1-2), 167-182.

Baron, R. A. (2008). The role of affect in the entrepreneurial process. Academy of Management Review, $33(2), 328-340$.

Baron, R. A., \& Tang, J. (2011). The role of entrepreneurs in firm-level innovation: Joint effects of positive affect, creativity, and environmental dynamism. Journal of Business Venturing, 26(1), 4960. 
Bazerman, M. (2001). Consumer research for consumers. Journal of Consumer Research, 27(4), 499-504.

Bernardo, A. E., \& Welch, I. (2001). On the evolution of overconfidence and entrepreneurs. Journal of Economics \& Management Strategy, 10(3), 301-330.

Bingham, C. B., \& Eisenhardt, K. (2001). Decoupling resources from the resource-based view: unraveling multiple ties to competitive advantage. Working Paper-Stanford Technology Ventures Program.

Bird, B. J. (1992). The roman god mercury: An entrepreneurial archetype. Journal of Management Inquiry, 1(3), 205-212.

Bless, H., Fiedler, K., \& Strack, F. (2004). Social cognition: How individuals construct social reality. Psychology Press (1st ed.). Sussex, UK: Psychology Press.

Bornstein, B. H., \& Emler, A. C. (2001). Rationality in medical decision making: A review of the literature on doctors' decision-making biases. Journal of Evaluation in Clinical Practice, 7(2), 97107.

Brase, G. L., Cosmides, L., \& Tooby, J. (1998). Individuation, counting, and statistical inference: The role of frequency and whole-object representations in judgment under uncertainty. Journal of Experimental Psychology: General, 127(1), 3-21.

Bröder, A., \& Eichler, A. (2006). The use of recognition information and additional cues in inferences from memory. Acta Psychologica, 121(3), 275-84.

Bryant, P. (2007). Self-regulation and decision heuristics in entrepreneurial opportunity evaluation and exploitation. Management Decision, 45(4), 732-748.

Burmeister, K., \& Schade, C. (2007). Are entrepreneurs' decisions more biased? An experimental investigation of the susceptibility to status quo bias. Journal of Business Venturing, 22(3), 340-362.

Busenitz, L. W. (1999). Entrepreneurial risk and strategic decision making: It's a matter of perspective. The Journal of Applied Behavioral Science, 35(3), 325-340.

Busenitz, L. W., \& Barney, J. B. (1997). Differences between entrepreneurs and managers in large organizations: Biases and heuristics in strategic decision-making. Journal of Business Venturing, 12(1), 9-30.

Busenitz, L. W., \& Lau, C.M. (1996). A cross-cultural cognitive model of new venture creation. Entrepreneurship: Theory and Practice, 20(4), 25.

Byrne, D., \& Griffitt, W. (1973). Interpersonal attraction. Annual Review of Psychology, 24(1), 317-336.

Cable, D. M., \& Shane, S. (1997). Approach to a prisoner' dilemma relationships capitalist. The Academy of Management Review, 22(1), 142-176.

Cacioppo, J. T. (2002). Foundations in Social Neuroscience. (J. T. Cacioppo, G. Bernston, R. Adolphs, C. S. Carter, R. Davidson, M. McClintock, ... S. Taylor, Eds.) (1st ed.). Boston, MS: Massachusetts Institute of Technology. 
Camerer, C., \& Lovallo, D. (1999). Overconfidence and excess entry: An experimental approach. American economic review, 89(1), 306-318.

Cardon, M. S., Foo, M.D., Shepherd, D., \& Wiklund, J. (2012). Exploring the heart: Entrepreneurial emotion is a hot topic. Entrepreneurship Theory and Practice, 36(1), 1-10.

Carr, J. C., \& Blettner, D. P. (2010). Cognitive control bias and decision-making in context: Implications for entrepreneurial founders of small firms. Frontier of Entrepreneurship Research, 30(6), 1-15.

Cassar, G. (2010). Are individuals entering self-employment overly optimistic? An empirical test of plans and projections on nascent entrepreneur expectations. Strategic Management Journal, 31(2), 822840.

Cassar, G., \& Craig, J. (2009). An investigation of hindsight bias in nascent venture activity. Journal of Business Venturing, 24(2), 149-164.

Chen, C. C., Greene, P. G., \& Crick, A. (1998). Does entrepreneurial self-efficacy distinguish entrepreneurs from managers? Journal of Business Venturing, 13(4), 295-316.

Cho, J. (2006). The mechanism of trust and distrust formation and their relational outcomes. Journal of Retailing, 82(1), 25-35.

Clore, G. L., Schwarz, N., \& Conway, M. (1994). Affective causes and consequences of social information processing. In R. S. Wyer \& T. K. Srull (Eds.), Handbook of social cognition: Basic processes (2nd ed., pp. 324-404). New York, NY: Psychology Press.

Cohen, L. J. (1981). Are there any a priori constraints on the study of rationality? Behavioral and Brain Sciences, 4(03), 359-370.

Cohen, W., \& Levinthal, D. (1990). Absorptive capacity: A new perspective on learning and innovation. Administrative Science Quarterly, 35(1), 128-152.

Cooper, A. C., Woo, C. Y., \& Dunkelberg, W. C. (1989). Entrepreneurship and the initial size of firms. Journal of Business Venturing, 4(5), 317-332.

Cosmides, L. (1996). Are humans good intuitive statisticians after all? Rethinking some conclusions from the literature on judgment under uncertainty. Cognition, 58(1), 1-73.

Coval, J. D., \& Moskowitz, T. J. (1999). Local equity preference in domestic portfolios. The Journal of Finance, 54(6), 2045-2073.

Cumming, D., \& Dai, N. (2010). Local bias in venture capital investments. Journal of Empirical Finance, $17(3), 362-380$.

De Carolis, D. M., Litzky, B. E., \& Eddleston, K. A. (2009). Why networks enhance the progress of new venture creation: The influence of social capital and cognition. Entrepreneurship Theory and Practice, 33(2), 527-545. 
De Carolis, D. M., \& Saparito, P. (2006). Social capital, cognition, and entrepreneurial opportunities: A theoretical framework. Entrepreneurship Theory and Practice, 30(1), 41-56.

Dimoka, A. (2010). What does the brain tell us about trust and distrust? Evidence from a functional neuroimaging study. Management Information Systems Quarterly, 34(2), 373 - 396.

Ebbers, J. J., \& Wijnberg, N. M. (2012). Nascent ventures competing for start-up capital: Matching reputations and investors. Journal of Business Venturing, 27(3), 372-384.

Einhorn, H., \& Hogarth, R. (1981). Behavioral decision theory: Processes of judgment and choice. Journal of Accounting Research, 19(1), 1-31.

Elstein, A. S., Schwartz, A., \& Schwarz, A. (2002). Clinical problem solving and diagnostic decision making: Selective review of the cognitive literature. BMJ, 324: 729.

Foo, M.D. (2011). Emotions and entrepreneurial opportunity evaluation. Entrepreneurship Theory and Practice, 35(2), 375-393.

Foo, M.D., Uy, M. A., \& Baron, R. A. (2009). How do feelings influence effort? An empirical study of entrepreneurs' affect and venture effort. Journal of Applied Psychology, 94(4), 1086-1094.

Forbes, D. P. (2005). Are some entrepreneurs more overconfident than others? Journal of Business Venturing, 20(5), 623-640.

Franke, N., Gruber, M., Harhoff, D., \& Henkel, J. (2006). What you are is what you like-similarity biases in venture capitalists' evaluations of start-up teams. Journal of Business Venturing, 21(6), 802-826.

Fredrickson, B. L. (2001). The role of positive emotions in positive psychology. The broaden-and-build theory of positive emotions. The American Psychologist, 56(3), 218-260.

Frese, M. (2009). Towards a psychology of entrepreneurship — an action theory perspective. Foundations and Trends in Entrepreneurship, 5(6), 437-496.

Frese, M., \& Gielnik, M. (2014). The psychology of entrepreneurship. Annual Review of Organizational Psychology and Organizational Behavior, 1, 413-438.

Gable, P., \& Harmon-Jones, E. (2010). The blues broaden, but the nasty narrows: Attentional consequences of negative affects low and high in motivational intensity. Psychological Science, 21(2), 211-5.

Gans, G., Jarke, M., Kethers, S., Lakemeyer, G., Ellrich, L., Funken, C., \& Meister, M. (2001). Requirements modeling for organization networks: A (dis)trust-based approach. In Proceedings Fifth IEEE International Symposium on Requirements Engineering (pp. 154-163). IEEE Comput. Soc.

Gigerenzer, G. (1996). On narrow norms and vague heuristics: A reply to Kahneman and Tversky. Psychological Review, 103(3), 592-596. 
Gigerenzer, G., \& Gaissmaier, W. (2011). Heuristic decision making. Annual Review of Psychology, 62, 451-82.

Gilovich, T., Griffin, D. W., \& Kahneman, D. (2002). The psychology of intuitive judgment: Heuristic and biases (1st ed., pp.855). Cambridge, UK: Cambridge University Press.

Gino, F., \& Moore, D. A. (2007). Effects of task difficulty on use of advice. Journal of Behavioral Decision Making, 20(1), 21-35.

Gladwin, T. N., Kennelly, J. J., \& Krause, T.S. (1995). Shifting paradigms for sustainable development: Implications for management theory and research. Academy of Management Review, 20(4), 874-907.

Goldstein, D. G., \& Gigerenzer, G. (2002). Models of ecological rationality: The recognition heuristic. Psychological Review, 109(1), 75-90.

Grégoire, D. A., Corbett, A. C., \& McMullen, J. S. (2011). The cognitive perspective in entrepreneurship: An agenda for future research. Journal of Management Studies, 48(6), 1443-1477.

Grichnik, D. (2008). Risky choices in new venture decisions - experimental evidence from Germany and the United States. Journal of International Entrepreneurship, 6(1), 22-47.

Gudmundsson, S. V., \& Lechner, C. (2013). Cognitive biases, organization, and entrepreneurial firm survival. European Management Journal, 31(3), 278-294.

Hahn, V. C., Frese, M., Binnewies, C., \& Schmitt, A. (2012). Happy and proactive? The role of hedonic and eudaimonic well-being in business owners' personal initiative. Entrepreneurship Theory and Practice, 36(1), 97-114.

Haidt, J. (2001). The emotional dog and its rational tail: A social intuitionist approach to moral judgment. Psychological Review, 108(4), 814-834.

Haley, U. C. V., \& Stumpf, S. A. (1989). Cognitive trails in strategic decision-making: Linking theories of personalities and cognitions. Journal of Management Studies, 26(5), 477-497.

Hardman, D. (2009). Judgment and decision making: Psychological perspectives (1st ed.). West Sussex, UK: Blackwell Publishing Ltd.

Harmon-Jones, E., \& Gable, P. A. (2008). Incorporating motivational intensity and direction into the study of emotions: Implications for brain mechanisms of emotion and cognition-emotion interactions. Netherlands Journal of Psychology, 64(4), 132-142.

Haselton, M., Nettle, D., Andrews, P. (2005). The handbook of evolutionary psychology. In D.Buss (Ed.),The evolution of cognitive bias (pp. 724-746). New Jersey, USA: Wiley.

Hayward, M. L., Forster, W. R., Sarasvathy, S. D., \& Fredrickson, B. L. (2010). Beyond hubris: How highly confident entrepreneurs rebound to venture again. Journal of Business Venturing, 25(6), 569578. 
Hayward, M. L., Shepherd, D. A., \& Griffin, D. (2006). A hubris theory of entrepreneurship. Management Science, 52(2), 160-172.

Hodgkinson, G. P., \& Healey, M. P. (2011). Psychological foundations of dynamic capabilities: Reflexion and reflection in strategic management. Strategic Management Journal, 32(13), 1500-1516.

Hogarth, R. M., \& Karelaia, N. (2012). Entrepreneurial success and failure: Confidence and fallible judgment. Organization Science, 23(6), 1733-1747.

Holcomb, T. R., Ireland, R. D., Holmes Jr., R. M., \& Hitt, M. A. (2009). Architecture of entrepreneurial learning: Exploring the knowledge, and action. Entrepreneurship Theory and Practice, 33(1), 167192.

Iverson, G., Brooks, B., \& Holdnack, J. (2008). Misdiagnosis of cognitive impairment in forensic neuropsychology. In R. Heilbronner (Ed.), Neuropsychology in the courtroom: Expert analysis of reports and testimony (1st ed., pp. 243-266). New York, NY: The Guilford Press.

Jolls, C., Sunstein, C. R., \& Thaler, R. H. (2000). A behavioral approach to law and economics. In C. R. Sunstein (Ed.), Behavioral law and economics (pp. 13-58). Cambrige, UK: Cambridge University Press.

Kahneman, D. (2003). Maps of bounded rationality: Psychology for behavioral economics. American Economic Association, 93(5), 1449-1475.

Kahneman, D., \& Fredekerik, S. (2002). Representativeness revisited: Attribute substitution in intuitive judgment. In T. Gilovich, D. Griffin, \& D. Kahneman (Eds.), Heuristics of intuitive judgment: Extensions and applications. New York, NY: Cambridge University Press.

Kahneman, D., \& Lovallo, D. (1993). Timid choices and bold forecasts: A cognitive perspective on risk taking. Management Science, 39(1), 17-31.

Kahneman, D., \& Tversky, A. (1979). Prospect theory: An analysis of decision under risk. Econometrica, 47(2), 263-291.

Kahneman, D., \& Tversky, A. (1982). Judgment under uncertainty: Heuristics and biases. (D. Kahneman, P. Slovic, \& A. Tversky, Eds.). Cambrige, UK: Cambridge University Press.

Kahneman, D., \& Tversky, A. (1984). Choices, values, and frames. American Psychologist, 39(4), 341350.

Kahneman, D., \& Tversky, A. (1996). On the reality of cognitive illusions. Psychological Review, 103(3), 582-591.

Keh, H. T., Foo, M. Der, \& Lim, B. C. (2002). Opportunity evaluation under risky conditions: The cognitive processes of entrepreneurs. Entrepreneurship Theory and Practice, 27(2), 125-148.

Khanin, D., \& Mahto R. (2013). Do venture capitalists have a continuation bias?. Journal of Entrepreneurship, 22(2), 203-222. 
Kiss, A. N., Danis, W. M., \& Cavusgil, S. T. (2012). International entrepreneurship research in emerging economies: A critical review and research agenda. Journal of Business Venturing, 27(2), 266-290.

Klauer, K. C., Musch, J., \& Naumer, B. (2000). On belief bias in syllogistic reasoning. Psychological Review, 107(4), 852-884.

Klotz, A. C., Hmieleski, K. M., Bradley, B. H., \& Busenitz, L. W. (2014). New venture teams: A review of the literature and roadmap for future research. Journal of Management, 40(1), 226-255.

Knight, F. H. (1921). Risk, uncertainty and profit (1st ed.). New York, NY: Sentry Press.

Koellinger, P., Minniti, M., \& Schade, C. (2007). "I think I can, I think I can": Overconfidence and entrepreneurial behavior. Journal of Economic Psychology, 28(4), 502-527.

Krueger, N. (2005). The cognitive psychology of entrepreneurship. In Z. J. Acs \& D. B. Audretsch (Eds.), Handbook of entrepreneurship research (pp. 105-140). New York, NY: Kluwer Academic Publishers.

Kwan, V. S. Y., John, O. P., Kenny, D. A., Bond, M. H., \& Robins, R. W. (2004). Reconceptualizing individual differences in self-enhancement bias: An interpersonal approach. Psychological Review, 111(1), 94-110.

Langer, E. (1975). The illusion of control. Journal of Personality and Social Psychology, 32(2), 311-328.

Langevoort, D. C. (1998). Behavioral theories of judgment and decision making in legal scholarship: A literature review. Vanderbilt Law Review, 51, 1499-1526.

Lee, J., \& Huynh, M. (2005). An integrative model of trust on IT outsourcing: From the service receiver's perspective. PACIS 2005 Proceedings.

Levin, I. P., Gaeth, G. J., Schreiber, J., \& Lauriola, M. (2002). A new look at framing effects: Distribution of effect sizes, individual differences, and independence of types of effects. Organizational Behavior and Human Decision Processes, 88(1), 411-429.

Lowe, R. A., \& Ziedonis, A. A. (2006). Overoptimism and the performance of entrepreneurial firms. Management Science, 52(2), 173-186.

Lyubomirsky, S., King, L., \& Diener, E. (2005). The benefits of frequent positive affect: Does happiness lead to success? Psychological Bulletin, 131(6), 803-855.

Mackie, D. M., \& Worth, L. T. (1989). Processing deficits and the mediation of positive affect in persuasion. Journal of Personality and Social Psychology, 57(1), 21-40.

Macmillan, I. C., Zemann, L., \& Subbanarasimha, P. N. (1987). Criteria distinguishing successful from unsuccessful ventures in the venture screening process. Journal of Business Venturing, 2(2), 123137.

Manimala, M. (1992). Entrepreneurial heuristics: A comparison between high PL (pioneering-innovative) and low PI ventures. Journal of Business Venturing, 7(6), 477-504- 
Mccarthy, A. M., Schoorman, F. D., \& Cooper, A. C. (1993). Reinvestment decision by entrepreneurs: Rational decision-making or escalation of commitment? Journal of Business Venturing, 8, 9-24.

McGrath, R., \& Desai, S. (2010). Connecting the study of entrepreneurship and theories of capitalist progress: An epilog. In Z. J. Acs \& D. B. Audretsch (Eds.), Handbook of entrepreneurship research (pp. 639-660). New York, NY: Springer New York.

McGraw, K. O., \& Wong, S.P.,(1996). Forming inferences about some intraclass correlation coefficients. Psychological Methods, 1, 30-46.

Milkman, K. L., Chugh, D., \& Bazerman, M. H. (2009). How can decision making be improved? Perspectives on Psychological Science, 4(4), 379-383.

Mitchell, R. K., Busenitz, L. W., Bird, B., Gaglio, C. M., McMullen, J. S., Morse, E. A., \& Smith, J. B. (2007). The central question in entrepreneurial cognition research. Entrepreneurship Theory and Practice, 31(1), 1-27.

Mitchell, R. K., Busenitz, L. W., Lant, T., McDougall, P. P., Morse, E. A., \& Smith, J. B. (2002). Toward a theory of entrepreneurial cognition: Rethinking the people side of entrepreneurship research. Entrepreneurship Theory and Practice, 27(2), 93-104.

Mitchell, R. K., Mitchell, J. R., \& Smith, J. B. (2008). Inside opportunity formation: Enterprise failure, cognition, and the creation of opportunities. Strategic Entrepreneurship Journal, 2(3), 225-242.

Mitchell, R. K., Smith, B., Seawright, K. W., \& Morse, E. A. (2000). Cross-cultural cognitions and the venture creation decision. Academy of Management Journal, 43(5), 974-993.

Moore, D. A., \& Cain, D. M. (2007). Overconfidence and underconfidence: When and why people underestimate (and overestimate) the competition. Organizational Behavior and Human Decision Processes, 103(2), 197-213.

Moore, D. A., \& Healy, P. J. (2008). The trouble with overconfidence. Psychological Review, 115(2), 502-17.

Moroz, P. W., \& Hindle, K. (2012). Entrepreneurship as a process: Toward harmonizing multiple perspectives. Entrepreneurship Theory and Practice, 36(4), 781-818.

Murnieks, C. Y., Haynie, J. M., Wiltbank, R. E., \& Harting, T. (2011). "I like how you think": Similarity as an interaction bias in the investor-entrepreneur dyad. Journal of Management Studies, 48(7), $1533-1561$.

O'Connor, A. M., Légaré, F., \& Stacey, D. (2003). Risk communication in practice: The contribution of decision aids. British Medical Journal, 327(7417), 736-740.

O’Connor, A. M., Rostom, A., Fiset, V., Tetroe, J., Entwistle, V., Llewellyn-Thomas, H., ... Jones, J. (1999). Decision aids for patients facing health treatment or screening decisions: Systematic review. British Medical Journal, 319(7212), 731-734. 
Omodei, M. M., \& McLennan, J. (2000). Conceptualizing and measuring global interpersonal mistrusttrust. The Journal of Social Psychology, 140(3), 279-294.

Oswald, M., \& Grosjean, S. (2004). Confirmation bias. In R. Pohl (Ed.), Cognitive illusions : A handbook on fallacies and biases in thinking, judgement and memory (pp. 79-96). New York, NY: Psychology Press.

Park, J., \& Banaji, M. R. (2000). Mood and heuristics: The influence of happy and sad states on sensitivity and bias in stereotyping. Journal of Personality and Social Psychology, 78(6), 10051023.

Parker, S. C. (2009). Can cognitive biases explain venture team homophily? Strategic Entrepreneurship Journal, 3(1), 67-83.

Parwada, J. T. (2008). The genesis of home bias? The location and portfolio choices of investment company start-ups. Journal of Financial and Quantitative Analysis, 43(1), 245-266.

Petty, J. S., \& Gruber, M. (2011). "In pursuit of the real deal.” Journal of Business Venturing, 26(2), 172188.

Pinker, S. (1997). How the mind works. 1997 (1st ed.). New York, NY: W.W. Norton \& Company.

Podoynitsyna, K., Van der Bij, H., \& Song, M. (2012). The role of mixed emotions in the risk perception of novice and serial entrepreneurs. Entrepreneurship Theory and Practice, 36(1), 115-140.

Pronin, E., Lin, D. Y., \& Ross, L. (2002). The bias blind spot: Perceptions of bias in self versus others. Personality and Social Psychology Bulletin, 28(3), 369-381.

Puri, M., \& Robinson, D. (2007). Optimism and economic choice. Journal of Financial Economics, 86(1), 71-99.

Rachlinski, J. J. (2004). Heuristics, biases and governance. In D. J. Koehler \& N. Harvey (Eds.), Blackwell handbook of judgment and decision making (pp. 567-584). Malden, MA: Blackwell Publishing Ltd.

Rieskamp, J., \& Hoffrage, U. (2008). Inferences under time pressure: How opportunity costs affect strategy selection. Acta Psychologica, 127(2), 258-76.

Rieskamp, J., \& Otto, P. E. (2006). SSL: A theory of how people learn to select strategies. Journal of Experimental Psychology: General, 135(2), 207-236.

Rode, C., Cosmides, L., Hell, W., \& Tooby, J. (1999). When and why do people avoid unknown probabilities in decisions under uncertainty? Testing some predictions from optimal foraging theory. Cognition, 72(3), 269-304.

Rogoff, E. G., Lee, M.S., \& Sub, D.C. (2004). "Who done it?" Attributions by entrepreneurs and experts of the factors that cause and impede small business success. Journal of Small Business Management, 42(4), 364-376. 
Rosenwald, M. S. (2010). Second Life's virtual money can become real-life cash. The Washington Post. Washington D.C.

Rousseau, D. M., Sitkin, S. B., Burt, R. S., \& Camerer, C. (1998). Not so different after all: A crossdiscipline view of trust. Academy of Management Review, 23(3), 393-404.

Russo, J., \& Schoemaker, P. (1992). Managing overconfidence. Sloan Management Review, 33(2), 7-17.

Samuelson, W., \& Zeckhauser, R. (1988). Status quo bias in decision making. Journal of Risk and Uncertainty, 1(1), 7-59.

Sánchez, J. C., Carballo, T., \& Gutiérrez, A. (2011). The entrepreneur from a cognitive approach. Psicothema, 23(3), 433-8.

Sandri, S., Schade, C., Mußhoff, O., \& Odening, M. (2010). Holding on for too long? An experimental study on inertia in entrepreneurs' and non-entrepreneurs' disinvestment choices. Journal of Economic Behavior \& Organization, 76(1), 30-44.

Sanna, L. J., \& Schwarz, N. (2003). Debiasing the hindsight bias: The role of accessibility experiences and (mis)attributions. Journal of Experimental Social Psychology, 39(3), 287-295.

Sanna, L. J., Schwarz, N., \& Stocker, S. L. (2002). When debiasing backfires: Accessible content and accessibility experiences in debiasing hindsight. Journal of Experimental Psychology: Learning, Memory and Cognition, 28(3), 497-502.

Sarasvathy, S. D. (2001). Causation and effectuation: Toward a theoretical shift from economic inevitability to entrepreneurial contigency. Academy of Management Review, 26(2), 243-263.

Schade, C., \& Koellinger, P. (2007). Heuristics, biases, and the behavior of entrepreneurs. In M. Minniti (Ed.), Entrepreneurship: The engine of growth (pp. 41-63). Westport, CT: Praeger Publishers.

Shanteau, J. (1989). Cognitive heuristics and biases in behavioral auditing: Review, comments and observations. Accounting, Organizations and Society, 14(1), 165-177.

Sharot, T. (2011). The optimism bias. Current Biology, 21(23), 941-945.

Shepherd, D. A. (2010). Multilevel entrepreneurship research: Opportunities for studying entrepreneurial decision making. Journal of Management, 37(2), 412-420.

Shepherd, D. A., Wiklund, J., \& Haynie, J. M. (2009). Moving forward: Balancing the financial and emotional costs of business failure. Journal of Business Venturing, 24(2), 134-148.

Shepherd, D. A., Williams, T. A., \& Patzelt, H. (2015). Thinking about entrepreneurial decision making: Review and research agenda. Journal of Management, 41(1), 11-46.

Shepherd, D. A., Zacharakis, A., \& Baron, R. A. (2003). VCs' decision processes. Journal of Business Venturing, 18(3), 381-401. 
Simon, M., \& Houghton, S. M. (2002). The relationship among biases, misperceptions, and the introduction of pioneering products: Examining differences in venture decision contexts. Entrepreneurship Theory and Practice, 27(2), 105-124.

Simon, M., \& Houghton, S. M. (2003). The relationship between overconfidence and the introduction of risky products: Evidence from a field study. Academy of Management Journal, 46(2), 139-149.

Simon, M., Houghton, S. M., \& Aquino, K. (2000). Cognitive biases, risk perception, and venture formation: How individuals decide to start companies. Journal of Business Venturing, 15(2), 113134.

Simon, M., \& Shrader, R. C. (2012). Entrepreneurial actions and optimistic overconfidence: The role of motivated reasoning in new product introductions. Journal of Business Venturing, 27(3), 291-309.

Smith, B. R., Matthews, C. H., \& Schenkel, M. T. (2009). Differences in entrepreneurial opportunities: The role of tacitness and codification in opportunity identification. Journal of Small Business Management, 47(1), 38-57.

Solomon, I., \& Trotman, K. T. (2003). Experimental judgment and decision research in auditing: The first 25 years of AOS. Accounting, Organizations and Society, 28(4), 395-412.

Stacey, D., Bennett, C. L., Barry, M. J., Col, N. F., Eden, K. B., Holmes-Rovner, M., ... Thomson, R. (2011). Decision aids for people facing health treatment or screening decisions. The Cochrane Database of Systematic Reviews, (10), 1-59.

Stanovich, K. (2009). Decision making and rationality in the modern world (Fundamentals in cognition) (1st ed.). New York, NY: Oxford University Press.

Stanovich, K. E. (1999). Who is rational?: Studies of individual differences in reasoning (1st ed.). New Jersey, NJ: Psychology Press.

Stanovich, K. E., \& West, R. F. (2008). On the failure of cognitive ability to predict myside and one-sided thinking biases. Thinking and reasoning, 14(2), 129-167.

Staw, B. M. (1976). Knee-deep in the big muddy: A study of escalating commitment to a chosen course of action. Organizational Behavior and Human Performance, 16(1), 27-44.

Staw, B. M. (1977). Escalation: The determinants of commitment to a chosen course of action. Human Relations, 30(5), 431-450.

Stein, E. (1996). Without good reason: The rationality debate in philosophy and cognitive science (1st ed.). Oxford, UK: Clarendon Press Oxford.

Taylor, R. N. (1975). Age and experience as determinants of managerial information processing and decision making performance. Academy of Management Journal, 18(1), 74-81.

Tetlock, P., \& Mellers, B. (2002). The great rationality debate. Psychological Science, 13(1), 94-99. 
Todd, P. M., \& Gigerenzer, G. (2003). Bounding rationality to the world. Journal of Economic Psychology, 24(2), 143-165.

Todd, P. M., \& Gigerenzer, G. (2007). Environments that make us smart: Ecological rationality. Current Directions in Psychological Science, 16(3), 167-171.

Toft-Kehler, R., \& Wennberg, K., \& Kim, P. (2014). Practice makes perfect: Entrepreneurial-experience curves and venture performance. Journal of Business Venturing, 29(4), 453-470.

Tranfield, D., Denyer, D., \& Smart, P. (2003). Towards a methodology for developing evidence-informed management knowledge by means of systematic review. British Journal of Management, 14(3), $207-222$.

Tversky, A., \& Kahneman, D. (1973). Availability: A heuristic for judging frequency and probability. Cognitive Psychology, 5(2), 207-232.

Tversky, A., \& Kahneman, D. (1974). Judgment under uncertainty: Heuristics and biases. Science, 185(4157), 1124-1131.

Van Eerde, W., \& Thierry, H. (1996). Vroom's expectancy models and work-related criteria: A metaanalysis. Journal of Applied Psychology, 81(5), 575-586.

Volz, K. G., \& Gigerenzer, G. (2012). Cognitive processes in decisions under risk are not the same as in decisions under uncertainty. Frontiers in Neuroscience, 6, Article 105.

Wadeson, N. (2006). Cognitive aspects of entrepreneurship: Decision-making and attributes to risk. In M. Casson, B. Yeung, A. Basu, \& N. Wadeson (Eds.), The oxford handbook of entrepreneurship (1st ed., pp. 91-113). New York, NY: Oxford University Press.

Wickham, P. a. (2003). The representativeness heuristic in judgements involving entrepreneurial success and failure. Management Decision, 41(2), 156-167.

Wilcox, C. (2011). Bias: The unconscious deceiver ( $1^{\text {st }}$ ed., pp. 280). Bloomington, US: Xlibris Corporation.

Winter, S. G., \& Nelson, R. R. (1982). An evolutionary theory of economic change. University of Illinois at Urbana-Champaign's Academy for Entrepreneurial Leadership Historical Research Reference in Entrepreneurship.

Winterfeldt, D. Von, \& Edwards, W. (1986). Decision analysis and behavioral research (1st ed., Vol. 604). Cambrige, UK: Cambridge University Press.

Wu, B., \& Knott, A. M. (2006). Entrepreneurial risk and market entry. Management Science, 52(9), $1315-1330$.

Xiao, S., \& Benbasat, I. (2003). The formation of trust and distrust in recommendation agents in repeated interactions. In Proceedings of the 5th International Conference on Electronic Commerce ICEC '03 (pp. 287-293). New York, NY: ACM Press. 
Yates, J. F., Lee, J. W., \& Bush, J. G. (1997). General knowledge overconfidence: Cross-national variations, response style, and "reality". Organizational behavior and human decision processes, 70(2), 87-94.

Yates, J. F., Lee, J. W., Shinotsuka, H., Patalano, A. L., \& Sieck, W. R. (1998). Cross-cultural variations in probability judgment accuracy: Beyond general knowledge overconfidence?. Organizational Behavior and Human Decision Processes, 74(2), 89-117.

Yu, T., \& Cannella, A. A. (2012). A comprehensive review of multimarket competition research. Journal of Management, 39(1), 76-109.

Zacharakis, A. L., \& Meyer, G. D. (2000). The potential of actuarial decision models: Can they improve the venture capital investment decision? Journal of Business Venturing, 15(4), 323-346.

Zacharakis, A. L., \& Shepherd, D. A. (2001). The nature of information and overconfidence on venture capitalists' decision making. Journal of Business Venturing, 16(4), 311-332.

Zhang, S. X., \& Babovic, V. (2011). An evolutionary real options framework for the design and management of projects and systems with complex real options and exercising conditions. Decision Support Systems, 51(1), 119-129.

Zhang, S. X., Cueto, J., \& Vassolo, R. (2014). Effectuation and causation bias entrepreneur differently. In DRUID Conference, Copenhagen.

Zhao, H., Seibert, S. E., \& Hills, G. E. (2005). The mediating role of self-efficacy in the development of entrepreneurial intentions. The Journal of Applied Psychology, 90(6), 1265-72.

Ziegler, C.N., \& Lausen, G. (2005). Propagation models for trust and distrust in social networks. Information Systems Frontiers, 7(4-5), 337-358. 


\section{TABLES}

Table 1. Selected Articles Studying Entrepreneurial Biases (The Italics Denote Conceptual Papers)

\begin{tabular}{|c|c|c|c|c|}
\hline Author & Purpose & Method & Sample & Bias \\
\hline $\begin{array}{l}\text { McCarthy et } \\
\text { al. (1993) }\end{array}$ & $\begin{array}{l}\text { Examine the presence of escalation commitment in } \\
\text { reinvestment decisions by entrepreneurs }\end{array}$ & Survey & 1112 firms in the US & $\begin{array}{l}\text { Overconfidence, } \\
\text { escalation of } \\
\text { commitment }\end{array}$ \\
\hline $\begin{array}{l}\text { Busenitz \& } \\
\text { Barney (1997) }\end{array}$ & $\begin{array}{l}\text { Examine differences in the decision-making processes } \\
\text { used by entrepreneurs and managers in large organizations }\end{array}$ & $\begin{array}{l}\text { Survey and } \\
\text { scenario technique }\end{array}$ & $\begin{array}{l}124 \text { entrepreneurs and } \\
95 \text { managers in the US }\end{array}$ & $\begin{array}{l}\text { Overconfidence, } \\
\text { representativeness }\end{array}$ \\
\hline $\begin{array}{l}\text { Cable \& Shane } \\
\text { (1997) }\end{array}$ & $\begin{array}{l}\text { Study the decision to cooperate based on implicit } \\
\text { similarities in the entrepreneur-VC relationship }\end{array}$ & Conceptual & - & Similarity \\
\hline $\begin{array}{l}\text { Busenitz } \\
(1999)\end{array}$ & $\begin{array}{l}\text { Examine entrepreneurial risk through the lens of cognitive } \\
\text { psychology and decision-making }\end{array}$ & Survey & $\begin{array}{l}176 \text { entrepreneurs and } \\
95 \text { managers in the US }\end{array}$ & $\begin{array}{l}\text { Overconfidence, } \\
\text { representativeness }\end{array}$ \\
\hline $\begin{array}{l}\text { Coval \& } \\
\text { Moskowitz } \\
\text { (1999) }\end{array}$ & Study the local equity preference in domestic portfolios & Secondary data & $\begin{array}{l}10 \text { fund managers in the } \\
\text { US }\end{array}$ & Local bias (similarity) \\
\hline $\begin{array}{l}\text { Simon et al. } \\
(2000)\end{array}$ & $\begin{array}{l}\text { Explore how individuals cope with the risks inherent in } \\
\text { their decisions }\end{array}$ & $\begin{array}{l}\text { Survey and } \\
\text { scenario technique }\end{array}$ & $\begin{array}{l}191 \text { MBA students in } \\
\text { the US }\end{array}$ & $\begin{array}{l}\text { Overconfidence, } \\
\text { illusion of control, law } \\
\text { of small numbers }\end{array}$ \\
\hline $\begin{array}{l}\text { Bernardo \& } \\
\text { Welch (2001) }\end{array}$ & Analyze how overconfident behavior persists & Simulation & - & Overconfidence \\
\hline $\begin{array}{l}\text { Zacharakis \& } \\
\text { Shepherd } \\
(2001)\end{array}$ & $\begin{array}{l}\text { Investigate if VCs are overconfident in their decision- } \\
\text { making process }\end{array}$ & Conjoint analysis & $51 \mathrm{VCs}$ in the US & Overconfidence \\
\hline $\begin{array}{l}\text { Keh et al. } \\
(2002)\end{array}$ & Examine opportunity evaluation under risky conditions & $\begin{array}{l}\text { Survey and } \\
\text { scenario technique }\end{array}$ & $\begin{array}{l}77 \text { owners of SMEs in } \\
\text { Singapore }\end{array}$ & $\begin{array}{l}\text { Illusion of control, law } \\
\text { of small numbers, } \\
\text { overconfidence, } \\
\text { planning fallacy }\end{array}$ \\
\hline
\end{tabular}


Simon \&

Analyze the relationships among biases, misperceptions,

Houghton

(2002)

Simon \&

Houghton

(2003)

Wickham

(2003)

Rogoff et al.

Forbes (2005) and the introduction of pioneering products

Conceptual

Examine the effects of overconfidence on ill-structured decisions

Demonstrate the impact of representativeness on decision quality

Analyze the existence of a self-serving attribution bias when entrepreneurs enumerate the factors that contribute to or impede their business success

Examine differences in the degree to which entrepreneurs exhibit the overconfidence bias

Wu \& Knott

2006

De Carolis \& Saparito

(2006)

Franke et al.

Hayward et al. (2006)

Lowe \&

Ziedonis

Bryant (2007)

Burmeister \&

Shade (2007)
Analyze entrepreneurial risk propensity and market entry

Advance a model suggesting that entrepreneurial behavior is a result of the interplay of environments (social networks) and certain cognitive biases

Analyze biases arising from similarities between a venture capitalist and the members of a venture team

Develop a hubris theory of entrepreneurship to explain why so many new ventures are created under high risk

Analyze the impact of overoptimism on start-up performance

\section{Explore the role of self-regulation in decision heuristics}

Examine whether the empirical finding that entrepreneurs are more biased than other individuals, is generally valid
Survey and

interview

Experiment

Survey

Survey

Simulation and

Secondary data

Conceptual

Conjoint analysis

Conceptual

Secondary data

Conceptual

Experiment
Illusion of control, law of small numbers

55 managers of small computer companies in the US

155 entrepreneurship students in the UK

425 owners of small business and experts in the US

108 managers of new ventures in the US

Banking sector in the US

51 VCs in Munich, Berlin and Vienna

734 inventions from the University of California

427 students, 135

bankers and 240

entrepreneurs in
Overoptimism

Overconfidence

Representativeness

Self-serving attribution

Overconfidence.

Overconfidence

Overconfidence, illusion of control and representativeness

Similarity

Overconfidence

Representativeness

Status-Quo

(Representativeness) 
Koellinger et

al. (2007)

Moore \& Cain

Grichnik

(2008)

Parwada

(2008)

Cassar \&

Craig (2009)

De Carolis

(2009)

Parker (2009)

Barbosa \&

Fayolle (2010)

Carr \&

Blettner

(2010)

Cassar (2010)

Examine the rationality of the expectations and overoptimism of nascent entrepreneurs.

Cumming \& Examine local bias in VC investments

Study the antecedents of the decision to start a business

Aim to understand when and why people underestimate (and overestimate) the competition

Develop a model of entrepreneurial risk-taking behavior in different cultural settings

Analyze the determinants of the decision of firm location and stock selection of fund managers

Analyze how previous failures affect hindsight bias concerning the probability of venture formation

Analyze the Influence of social capital and cognition in the progress of new venture creation

Analyze how overoptimism and self-serving attributions explain homophily in start-up teams

Examine the effect of new information in risk perceptions and the decision to start a venture

Examine the effects of illusions of control on decision quality
Survey

Survey and

Secondary data

Experiment

Experiment and

survey

Secondary data

Survey

Survey

Simulation

Survey

Secondary data and interviews

Secondary data
Germany

40.000 entrepreneurs in

18 countries

(Over)confidence

91 university students in

the US

Overconfidence

252 entrepreneurship

students and

entrepreneurs in

Germany and the US

358 executives at 207

firms in the US

198 nascent

entrepreneurs in the US

269 students

entrepreneurs in the US

Entrepreneurs and students (number not indicated)

Overconfidence.

Local bias (similarity)

Hindsight bias

(Representativeness)

Illusion of control

Self-serving attribution

Availability and anchoring

163 small firm founders in the US

Illusion of control

386 entrepreneurs from

"Panel Study of

Entrepreneurial

Dynamics"

Investments from 1008

Local bias (similarity) 
Dai (2010)

Hayward et al. (2010)

Explain why more confident founders of failed new ventures are better positioned to start subsequent ventures

Sandri et al. Investigate the disinvestment behaviors of entrepreneurs when choices are irreversible

Murnieks et al. Investigate the extent to which similarity in decisionmaking process might bias opportunities

Simon \& Identify which entrepreneurial actions are associated with

Shrader (2011) an entrepreneur's failure

Ebbers \&

Wijnberg

(2012)

Hogarth \&

Karelaia

(2012)

Gudmundsson

\& Lechner

Khanin \&

Mahto (2013)

Toft-Kehler et al. (2014)
Analyze if the individual reputations of founders of nascent ventures can function as important signals to investors

Analyze if overconfidence causes excess entry and the high failure rates of market entry decisions

Build a multilevel model explaining the interplay of cognitive biases and cognitive make-up and its performance implications

Survey

Analyze if venture capitalist have a continuation bias

Analyze the experience-performance relationship and the impact of contextual similarity

Survey
VCs in the US

Conceptual $-$

Overconfidence

39 entrepreneurial

Experiment students and 37 nonstudents

Psychological inertia (Status-Quo)

Survey and conjoint analysis

$60 \mathrm{VCs}$ in the US

Similarity

Interview and survey

Case Study

Simulation

55 managers of small computer companies in the US

141 films' ventures from Netherlands

Similarity

Overconfidence

115 founders of small firms in Iceland

Overconfidence

$51 \mathrm{VCs}$ in the US

Continuation bias

Secondary data
Swedish founder and managers
Similarity 
Table 2. Biases Studied In Entrepreneurship

\begin{tabular}{|c|c|}
\hline Bias & Behaviors of People in Decision-making \\
\hline Overconfidence & $\begin{array}{l}\text { Perceive a subjective certainty higher than the objective accuracy } \\
\text { (Busenitz, 1999; Gudmundsson \& Lechner, 2013). }\end{array}$ \\
\hline Overoptimism & $\begin{array}{l}\text { Overestimate the likelihood of positive events and underestimate the } \\
\text { likelihood of negative events (Sharot 2011). }\end{array}$ \\
\hline $\begin{array}{l}\text { Self-serving } \\
\text { attribution }\end{array}$ & $\begin{array}{l}\text { Take credit for success while deny responsibility for failure (Rogoff et } \\
\text { al., 2004). }\end{array}$ \\
\hline Illusion of control & $\begin{array}{l}\text { Overemphasize how much skills, instead of chance, improve } \\
\text { performance (Langer, 1975). }\end{array}$ \\
\hline $\begin{array}{l}\text { The law of small } \\
\text { numbers }\end{array}$ & $\begin{array}{l}\text { Reach conclusions about a larger population using a limited sample } \\
\text { (Haley \& Stumpf, 1989). }\end{array}$ \\
\hline Similarity & $\begin{array}{l}\text { Tend to evaluate more positively those who are more similar to } \\
\text { themselves (Byrne \& Griffitt, 1973). }\end{array}$ \\
\hline Availability & $\begin{array}{l}\text { Make judgments about the probability of events based on how easy it is } \\
\text { to think of examples (Tversky \& Kahneman, 1974). }\end{array}$ \\
\hline Representativeness & $\begin{array}{l}\text { Use a familiar situation as a cognitive shortcut for making decisions } \\
\text { (Wadeson, 2006). }\end{array}$ \\
\hline Status-Quo & Repeat a previous choice overly often (Samuelson \& Zeckhauser, 1988). \\
\hline Planning fallacy & $\begin{array}{l}\text { Underestimate the time needed for future tasks (Kahneman \& Lovallo, } \\
\text { 1993). }\end{array}$ \\
\hline $\begin{array}{l}\text { Escalation of } \\
\text { commitment }\end{array}$ & $\begin{array}{l}\text { Persist unduly with unsuccessful initiatives or courses of action (Staw, } \\
\text { 1977). }\end{array}$ \\
\hline
\end{tabular}


Table 3. Unstudied Biases That Hold Potential Relevance to Entrepreneurship

\begin{tabular}{|c|c|c|}
\hline Bias & Definition & Source \\
\hline Illusory correlation & $\begin{array}{l}\text { Inaccurately perceive a relationship between two unrelated } \\
\text { events }\end{array}$ & $\begin{array}{l}\text { Tversky \& } \\
\text { Kahneman } \\
(1974)\end{array}$ \\
\hline Irrational escalation & Use prior investment to justify increased investment decision & Staw (1976) \\
\hline Base rate fallacy & $\begin{array}{l}\text { Ignore base rate information and focus on specific } \\
\text { information }\end{array}$ & Baron (1994) \\
\hline Ambiguity effect & $\begin{array}{l}\text { Avoid options whose probability seem "unknown" due to } \\
\text { missing information }\end{array}$ & Baron (1994) \\
\hline Belief bias & $\begin{array}{l}\text { Evaluate the logical strength of an argument based on the } \\
\text { believability of the conclusion }\end{array}$ & $\begin{array}{l}\text { Klauer et al. } \\
(2000)\end{array}$ \\
\hline Confirmation bias & $\begin{array}{l}\text { Search for, interpret, or recall information in a way that } \\
\text { confirms one's beliefs or hypotheses }\end{array}$ & $\begin{array}{l}\text { Oswald \& } \\
\text { Grosjean } \\
(2004)\end{array}$ \\
\hline Backfire effect & $\begin{array}{l}\text { Either do not update existing beliefs or believe them to be } \\
\text { stronger, in the face of contradictory evidence. }\end{array}$ & $\begin{array}{l}\text { Sanna et al. } \\
(2002)\end{array}$ \\
\hline Consistency bias & $\begin{array}{l}\text { Incorrectly remember one's past attitudes and behavior as } \\
\text { resembling present attitudes and behavior }\end{array}$ & $\begin{array}{l}\text { Cacioppo } \\
(2002)\end{array}$ \\
\hline Congruence bias & $\begin{array}{l}\text { Overly rely on directly testing a given hypothesis as well as } \\
\text { neglecting indirect testing }\end{array}$ & $\begin{array}{l}\text { Iverson et al. } \\
(2008)\end{array}$ \\
\hline Pseudo-certainty effect & $\begin{array}{l}\text { Make risk-averse choices if the expected outcome is positive, } \\
\text { but make risk-seeking choices to avoid negative outcomes }\end{array}$ & $\begin{array}{l}\text { (Hardman } \\
(2009)\end{array}$ \\
\hline
\end{tabular}


Table 4. Summary of Main Future Research Directions

\begin{tabular}{|c|c|c|}
\hline & Theme & Research Directions \\
\hline Definition & $\begin{array}{l}\text { Conceptualization } \\
\& \\
\text { operationalization }\end{array}$ & $\begin{array}{l}\text { To build future research on clear concepts (be especially cautious to } \\
\text { distinguish three distinct forms of overconfidence). }\end{array}$ \\
\hline \multirow{7}{*}{$\begin{array}{l}\text { Relationship } \\
\text { studies }\end{array}$} & $\begin{array}{l}\text { Risk-taking } \\
\text { behavior }\end{array}$ & $\begin{array}{l}\text { Processual path analysis on how biases impact risk-taking behaviors and } \\
\text { performance via different paths based on different theories. }\end{array}$ \\
\hline & $\begin{array}{l}\text { Role of } \\
\text { experience }\end{array}$ & $\begin{array}{l}\text { The relationship between experience (a complex concept itself to be } \\
\text { disentangled) and biases at both between-person and within-person } \\
\text { levels, in consideration of the quality of experience (can be positive or } \\
\text { negative). }\end{array}$ \\
\hline & $\begin{array}{l}\text { Decision } \\
\text { pdifficulty }\end{array}$ & $\begin{array}{l}\text { How task difficulty might mediate the relationships between contextual } \\
\text { factors (e.g. dynamism, complexity, hostility) and the three forms of } \\
\text { overconfidence. }\end{array}$ \\
\hline & Network & The relationships between entrepreneurs' network positions and biases \\
\hline & $\begin{array}{l}\text { Biases } \\
\text { unexamined to } \\
\text { date }\end{array}$ & $\begin{array}{l}\text { To study psycho-physics type of bias of the distortion in entrepreneurs' } \\
\text { perception of quantitative attributes (e.g. overweighing low probabilities } \\
\& \text { perception of optionality). Also see table } 3 \text { for a list of potentially } \\
\text { interesting biases for entrepreneurship research to cover in future. }\end{array}$ \\
\hline & \multirow[b]{2}{*}{ Research design } & Multi-level research on bias (e.g. national level and team level). \\
\hline & & $\begin{array}{l}\text { To distinguish, theorize and test biases under uncertainty from biases } \\
\text { under risk. }\end{array}$ \\
\hline \multirow{6}{*}{$\begin{array}{l}\text { Broader } \\
\text { situation }\end{array}$} & $\begin{array}{l}\text { Entrepreneurial } \\
\text { cognition }\end{array}$ & $\begin{array}{l}\text { Relationships between bias and other well-studied factors in cognitive } \\
\text { psychology such as heuristics, intelligence, and knowledge. }\end{array}$ \\
\hline & \multirow{2}{*}{$\begin{array}{l}\text { Entrepreneurial } \\
\text { emotion }\end{array}$} & How does affect influence bias and how does bias influence affect? \\
\hline & & $\begin{array}{l}\text { The interactions between cognitive biases and affect on entrepreneurial } \\
\text { actions. }\end{array}$ \\
\hline & \multirow{2}{*}{$\begin{array}{l}\text { Great rationality } \\
\text { debate }\end{array}$} & $\begin{array}{l}\text { The framing of entrepreneurial bias research based on recent advance in } \\
\text { cognitive psychology (esp. the great rationality debate) }\end{array}$ \\
\hline & & $\begin{array}{l}\text { The extent of the match between evolutionarily adapted mechanisms and } \\
\text { the representations in entrepreneurship. }\end{array}$ \\
\hline & Debiasing & $\begin{array}{l}\text { Effect of decision aids (venture evaluation form or business model } \\
\text { canvas) on biases. }\end{array}$ \\
\hline
\end{tabular}




\section{Table 5. Procedures and Criteria of the Article Search}

\begin{tabular}{|c|c|}
\hline Pro & Descriptions \\
\hline $\begin{array}{l}\text { 1. We started the search with an } \\
\text { initial set of keywords of biases, } \\
\text { entrepreneur (and its various } \\
\text { derived forms), and Venture } \\
\text { Capital (VC) in Journals listed } \\
\text { in Financial Times. }\end{array}$ & $\begin{array}{l}\text { 1. The top management journals in the Financial Times journal } \\
\text { list are used to identify the most prominent publications } \\
\text { relevant to the topic to start with. We read each of articles to } \\
\text { identify the biases studied. }\end{array}$ \\
\hline $\begin{array}{l}\text { 2. We identified the relevant } \\
\text { articles from step 1, and locate } \\
\text { the names of the biases studied } \\
\text { in those articles. The names of } \\
\text { the biases were added to the set } \\
\text { of keywords. And we then used } \\
\text { the enhanced list of keywords } \\
\text { to search in relevant subject } \\
\text { areas in Scopus. The end date } \\
\text { of the search is } 1^{\text {st }} \text { Jan } 2014 \text {. }\end{array}$ & $\begin{array}{l}\text { 2. The code we used in Scopus is the following: } \\
\text { (title-abs-key(entrepreneur) or title-abs-key(entrepreneurial) or } \\
\text { title-abs-key(entrepreneurship) or title-abs-key(venture capital) } \\
\text { or title-abs-key(venture capitalist)) and (title-abs-key(bias) or } \\
\text { title-abs-key(overconfidence) or title-abs-key(illusion of } \\
\text { control) or title-abs-key(availability) or title-abs-key(self- } \\
\text { serving attribution) or title-abs-key(status-quo) or title-abs- } \\
\text { key(representativeness) or title-abs-key(overoptimism) or title- } \\
\text { abs-key(planning fallacy) or title-abs-key(local bias) or title- } \\
\text { abs-key(hindsight bias) or title-abs-key(law of small numbers) }\end{array}$ \\
\hline $\begin{array}{l}\text { 3. One article that studied an } \\
\text { entrepreneurial bias but did not } \\
\text { name it using conventional } \\
\text { terminologies of biases was } \\
\text { later added to the list thanks to } \\
\text { a suggestion. }\end{array}$ & $\begin{array}{l}\text { or title-abs-key(similarity bias) or title-abs-key(self-serving } \\
\text { bias)) and (limit-to(language, "english")) and (limit- } \\
\text { to(doctype, "ar") or limit-to(doctype, "ip")) and (limit- } \\
\text { to(subjarea, "busi") or limit-to(subjarea, "soci") or limit- } \\
\text { to(subjarea, "psyc") or limit-to(subjarea, "deci") or limit- } \\
\text { to(subjarea, "mult") or limit-to(subjarea, "neur") or limit- } \\
\text { to(subjarea, "undefined") }\end{array}$ \\
\hline
\end{tabular}




\section{FIGURES}

\section{Antecedents}

Experience: Zacharakis \& Shepherd (2001), Forbes (2005), Hayward et al. (2006), -Koellinger et al. (2007)

Self-efficacy: Forbes (2005)

Ease of the task: Moore and Cain (2007)

\section{Strategic and organizational factors}

(decision comprehensiveness, strategic fit, (dis)trust, and key activities): Zacharakis \& Shepherd (2001), Bryant (2007), Simon \& Shrader (2012), De Carolis \& Saparito (2006), Gudmundsson \& Lechner (2013)

Context characteristics (hostility and dynamism of environment, riskiness of the context, unfamiliarity, and external investment): Zacharakis \& Shepherd (2001), Forbes (2005), Hayward et al. (2006), Simon \& Shrader (2012)

\section{Consequences}

Risk-taking: Simon et al. (2000), Keh et al. (2002), Simon \& Houghton (2003), Hayward et al. (2006), Lowe \& Ziedonis (2006), Wu \& Knott (2006), Grichnik (2008), Hogarth \& Karelaia (2012)

(- Karelaia (2012)

Formation of new venture team: Parker (2009)

Performance measures: Simon \& Houghton (2003), Rogoff (2004), Lowe \& Ziedonis (2006), Hayward et al. (2006), Koellinger et al. (2007), Cassar (2010), Gudmundson \& Lechner (2013)

Figure 1a: Overview of the Antecedents and Consequences of Make-Happy Biases 


\section{Antecedents}

\section{Consequences}

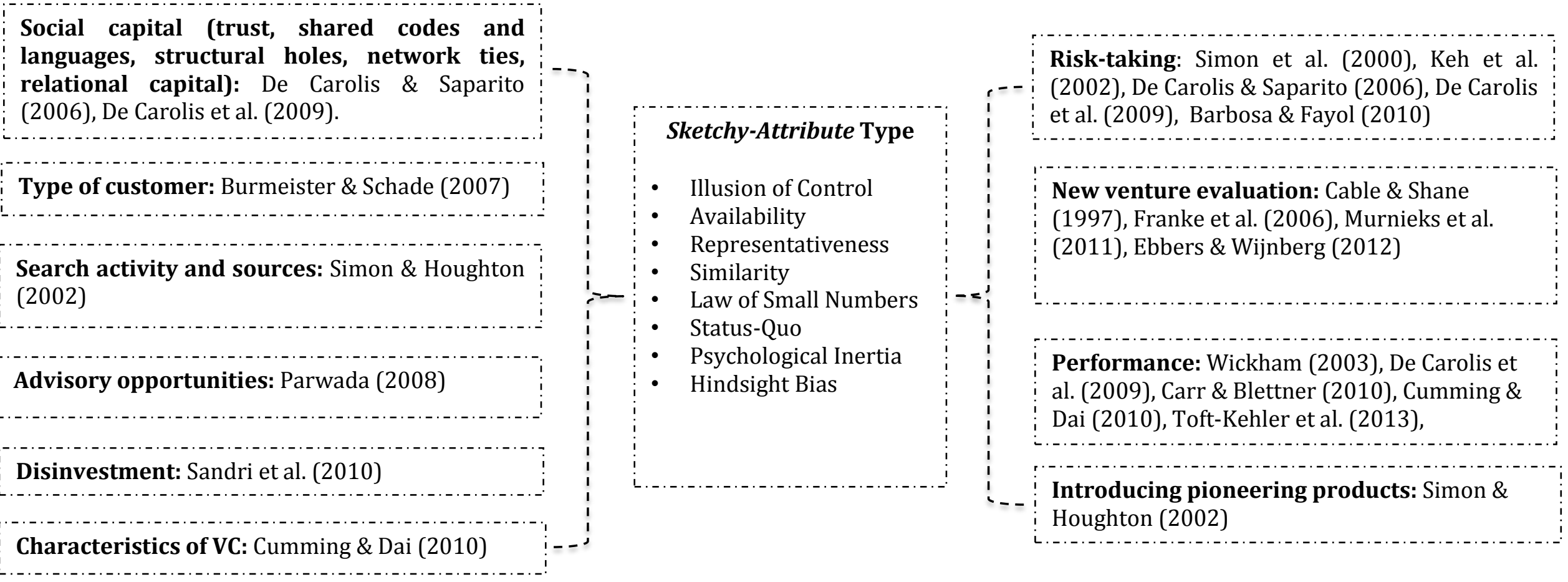

Figure 1b: Overview of the Antecedents and Consequences of Sketchy-Attribute Biases 